\title{
Collective timekeeping among cells of the master circadian clock
}

\author{
Jennifer A Evans
}

Department of Biomedical Sciences, Marquette University, Milwaukee, WI, USA

Correspondence should be addressed to J A Evans

Email jennifer.evans@marquette. edu

\begin{abstract}
The suprachiasmatic nucleus ( $\mathrm{SCN}$ ) of the anterior hypothalamus is the master circadian clock that coordinates daily rhythms in behavior and physiology in mammals. Like other hypothalamic nuclei, the SCN displays an impressive array of distinct cell types characterized by differences in neurotransmitter and neuropeptide expression. Individual SCN neurons and glia are able to display self-sustained circadian rhythms in cellular function that are regulated at the molecular level by a $24 \mathrm{~h}$ transcriptionaltranslational feedback loop. Remarkably, SCN cells are able to harmonize with one another to sustain coherent rhythms at the tissue level. Mechanisms of cellular communication in the SCN network are not completely understood, but recent progress has provided insight into the functional roles of several SCN signaling factors. This review discusses $\mathrm{SCN}$ organization, how intercellular communication is critical for maintaining network function, and the signaling mechanisms that play a role in this process. Despite recent progress, our understanding of SCN circuitry and coupling is far from complete. Further work is needed to map SCN circuitry fully and define the signaling mechanisms that allow for collective timekeeping in the SCN network.
\end{abstract}

\section{Introduction}

Daily rhythms in metabolic and endocrine function serve to anticipate predictable changes in the environment. These rhythms are not driven externally, but instead arise from an intrinsic cellular process that tracks the hours of the day. In other words, cells are daily clocks. Because cellular clocks tick with a period close to but not exactly $24 \mathrm{~h}$, they are referred to as 'circadian' (i.e. about a day). Biological timekeeping at the circadian timescale ensures that physiological and behavioral processes occur at the appropriate time of day. In this respect, it is an essential and ubiquitous feature of life on this planet. For example, glucocorticoid release surges just before wakening to proactively marshal important energy resources (Fig. 1, Takahashi et al. 1968). Likewise, the secretion of growth hormone is highest during slow-wave sleep when its ability to repair and strengthen bones is most effective (Fig. 1, Takahashi et al. 1968). In both cases, the timing of these rhythms is programed by a biological clock and influenced by sleep (Czeisler \& Klerman 1999). Over the last few decades, we have gained a deep understanding of the mechanisms that produce circadian timekeeping at the molecular and cellular levels. A key remaining question is how the numerous clock cells of our bodies form a coordinated system.

In mammals, the circadian system is a hierarchical collection of tissue clocks located throughout the brain and body (Mohawk et al. 2012). Many of these clocks are endocrine tissues that regulate hormone synthesis and release across the day (Fig. 1). Examples include the pituitary gland, the pineal gland, the adrenal gland,

This article is adapted from work presented at the European Biological Rhythms Society (EBRS)/World Congress of Chronobiology (WCC) meeting, 2-6 August 2015

The meeting was supported in part by the Journal of Endocrinology.04/26/2023 01:38:14PM 


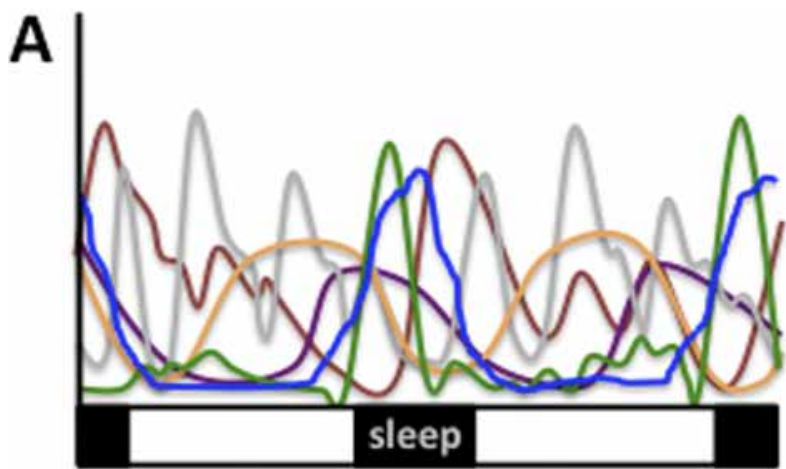

Melatonin Cortisol GH T3 Leptin Ghrelin

\section{B}

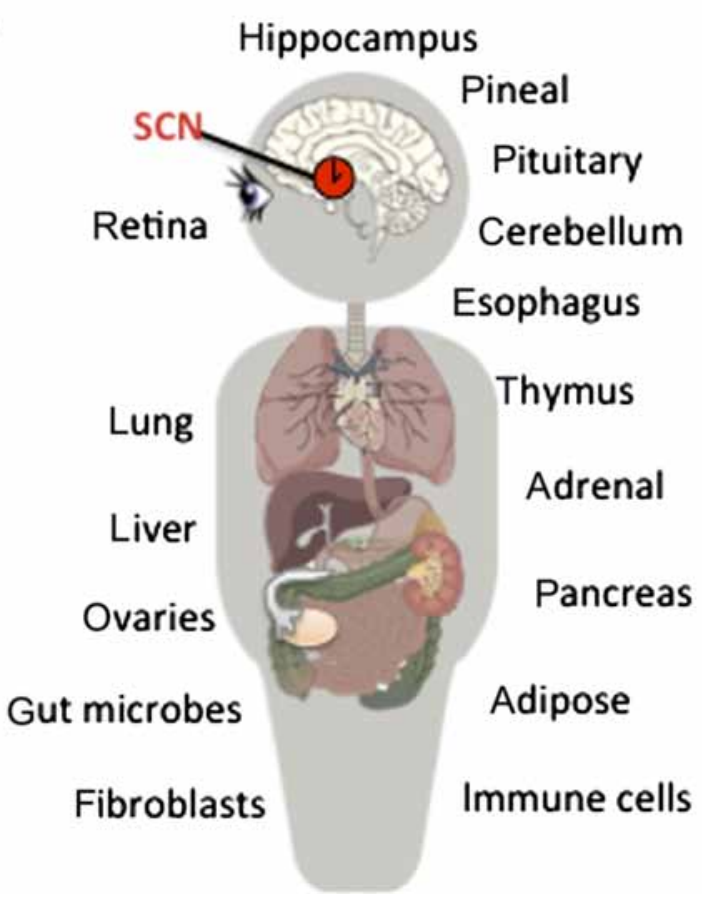

Figure 1

Daily hormone rhythms are regulated by the circadian timekeeping system. (A) Hormone release fluctuates over the circadian cycle, with peak times occurring at specific times of day. Figure based on data from (Takahashi et al. 1968, Gavrila et al. 2003, Koutkia et al. 2005, Natalucci et al. 2005, Russell et al. 2008). (B) The circadian timekeeping system is a hierarchical collection of tissue clocks located throughout the brain and body, many of which are endocrine tissues that regulate hormone synthesis and release across the day.

adipose tissue, and immune cells. These myriad body clocks are coordinated by the suprachiasmatic nucleus (SCN) of the anterior hypothalamus (Mohawk \& Takahashi 2011). The SCN serves as a master clock that receives cues from the environment (e.g., light) and relays them to downstream tissues through a variety of outputs (e.g. synaptic connections, humoral cues, behavioral and physiological control of sleep and body temperature). In this manner, the SCN harmonizes the various body clocks with one another and with the local time zone. Classic work demonstrates that the SCN is necessary for maintaining circadian rhythms in numerous processes, including sleep, feeding, drinking, melatonin production, and reproductive function (Klein et al. 1991, Weaver 1998). Given its extensive influence on endocrine function, understanding $\mathrm{SCN}$ circuitry is of prime importance.

The SCN is a neuronal network of cellular clocks that coordinate with one another to form a functional and cohesive population (Welsh et al. 2010). Like other hypothalamic nuclei, the SCN produces a diverse range of neurotransmitters and neuropeptides (van den Pol \& Tsujimoto 1985, Lee et al. 2013), which have been used to define distinct neuronal subclasses (Antle \& Silver 2005). In addition to relaying information to downstream clocks, SCN signaling molecules serve as local coupling factors that are important for maintaining network function. In particular, when SCN neurons are embedded in the network, they produce rhythms that are more precise, higher amplitude, and more robust than those displayed by isolated SCN neurons. Thus, intercellular communication within the SCN network is critically important for ensuring the fidelity of outputs to downstream tissues. Moreover, SCN neurons coordinate as a population to encode environmental conditions that are critical to survival (e.g. seasonal changes in day length). Despite its importance, the process by which SCN neurons influence one another is not completely understood. For instance, it is not known precisely how different SCN factors contribute to network function, how these signals are transmitted, and how they act to influence cellular rhythms. This review will describe recent progress that has advanced the understanding of SCN circuitry and highlight several issues that remain outstanding.

\section{Circadian timekeeping at the cellular level}

As a tissue, the SCN displays daily rhythms in numerous cellular processes, including metabolism, electrical activity, gene/protein expression, peptide release, and response to photic stimulation (Klein et al. 1991, Weaver 1998). Most of these rhythms persist when the SCN is studied in isolation from the environment and the rest of the brain. Thus, autonomous rhythmicity is an intrinsic property of the SCN itself. A key question posed almost immediately after this discovery was whether SCN rhythms are a network- or cellular-driven phenomenon.

Published by Bioscientifica Ltd 
The simple answer: SCN neurons are intrinsic clock cells. Pioneering work demonstrated that individual SCN neurons are capable of sustaining cellular rhythms even when dispersed at low density (Welsh et al. 1995, Herzog et al. 1998, Honma et al. 1998). Based on these results, it is commonly stated that SCN neurons are autonomous, selfsustained clocks. But the reality of the situation is slightly more complex because SCN neurons communicate with one another in ways that strengthen cellular rhythms (see more in next section).

But how does a cellular clock keep circadian time? Research conducted over the last few decades has revealed an elegant molecular mechanism that operates in nearly every cell of the body (Buhr \& Takahashi 2013). Briefly, cellular rhythms are generated by interlocking feedback loops controlling the daily transcription of 'clock genes' and 'clock-controlled genes' (Fig. 2). At its core, the molecular circadian clock is a delayed negative-feedback loop, with positive elements that drive transcription and negative elements that repress transcription on a daily basis. The positive elements are the transcription factors CLOCK and

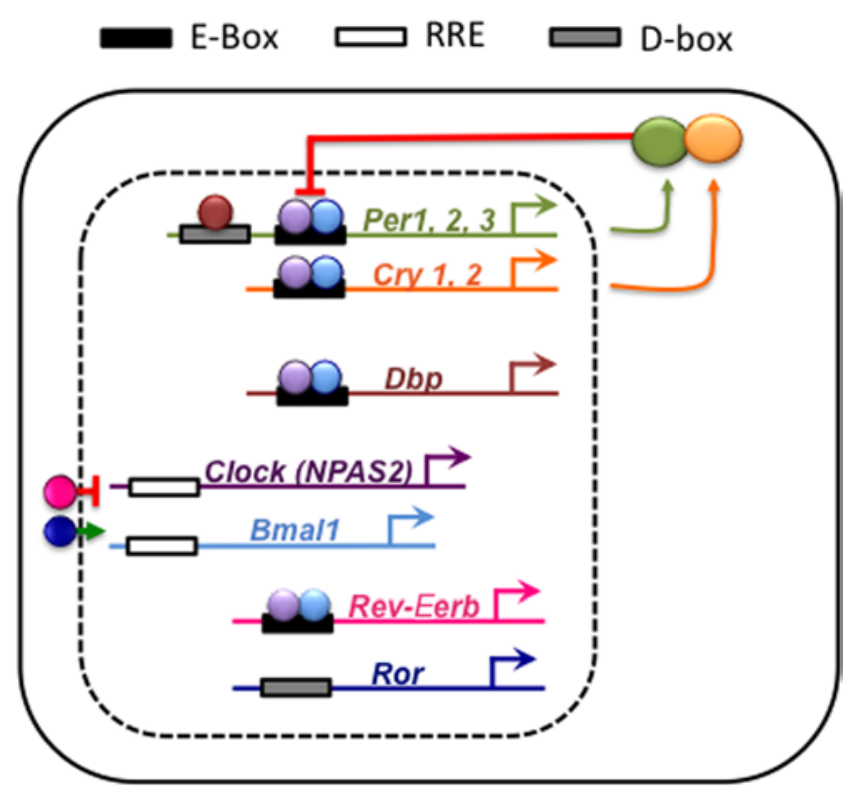

Figure 2

The molecular circadian clock comprises interlocking transcriptionaltranslational feedback loops. CLOCK and BMAL1 are transcription factors that bind to E-box elements within the promoter sequences of a variety of clock genes. The protein products of Period (Per) and Cryptochrome (Cry) genes form repressors that inhibit their own transcription. Additional feedback loops involve other clock genes that interact with the elements of the core loop to amplify and stabilize molecular clock function. For example, the protein products of Rev-Erb and Ror genes compete for binding at ROR elements to influence Bmal1 and Clock transcription. Further, the protein products of clock-controlled genes, such as $D b p$, can influence both downstream molecular targets and core clock genes by binding at $D$-box elements.
BMAL1, whereas the negative elements are PERIOD and CRYTOCHROME proteins. Daily transcription is initiated when CLOCK and BMAL1 form a dimer that activates the expression of a family of Period (Per1, Per2, Per3) and Cryptochrome genes (Cry1, Cry2). This increases the levels of PER and CRY proteins, which dimerize, translocate into the nucleus, and inhibit their own transcription by repressing CLOCK-BMAL1 function (Fig. 2). This transcriptional repression, along with ubiquitination and degradation, causes PER and CRY levels to decline. Falling levels of PER and CRY then allow for derepression of CLOCK-BMAL1, which reactivates the transcription of Per and Cry. And so, the cycle renews the following day. This type of negative-feedback mechanism forms the basis of circadian timekeeping in a wide range of organisms (bacteria, fungi, plants, insects, and mammals) although the genes involved differ across species (Mackey 2007).

It remains a key area of research to understand fully the molecular control of cellular rhythms (Zhang \& Kay 2010). With each passing day, our understanding of the circadian network at this level grows. We now appreciate that there are additional gene networks that regulate the core loop described above. For example, one interconnected loop regulates Bmal1 and Clock transcription via opposing actions of ROR and REV-ERB (Fig. 2). This ancillary loop regulates the precision, robustness, and amplitude of core clock gene expression. Also, there are numerous 'clockcontrolled genes' that are influenced by the molecular clock either directly or indirectly. For example, the transcription factor D-binding protein (DBP) is directly controlled by CLOCK-BMAL1 (Fig. 2). By regulating the timing of DBP expression, the core molecular clock can influence myriad downstream targets. To further demonstrate the interlocked nature of these feedback loops, DBP can influence Per transcription by binding to an upstream promoter sequence. Moreover, clock genes may contain additional regulatory elements (e.g., CRE) through which their expression is regulated by cellular and environmental signals. Collectively, the circadian molecular clock operates in nearly every cell of the body to regulate at least half the genome (Zhang et al. 2014).

In SCN neurons, the molecular oscillator controls myriad cellular processes (Kuhlman 2007). Notably, SCN neurons typically display daily rhythms in membrane potential with high firing during the day and low firing during the night (Brown \& Piggins 2007). The temporal patterning of SCN electrical activity has important implications for network signaling and outputs to downstream tissues, so this is a critical area of research. Yet this approach is often limited in the number of SCN

Published by Bioscientifica Ltd 
neurons that can be recorded at the same time. Recent technological advances enable a more comprehensive view of SCN network function using real-time imaging of molecular activity. Over the years, researchers have engineered an impressive array of mouse models with genetically encoded optical reporters (e.g. Per1-GFP, Per1luciferase, PER2::LUCIFERASE, Bmal1-luciferase, and Cry1-luciferase) that allow one to track molecular clock function in real time (Kuhlman et al. 2000, Yamaguchi et al. 2003, Yoo et al. 2004, Noguchi et al. 2010, Maywood et al. 2013). In addition, genetic mouse models and viral tools have been developed to monitor daily rhythms in $\mathrm{Ca}^{+2}$ and other intracellular signals (Enoki et al. 2012, Brancaccio et al. 2013, Irwin \& Allen 2013). Provided there is good penetrance and faithful recapitulation of native molecular function, real-time imaging approaches provide an unprecedented view of the dynamic clock because they can be used to monitor hundreds of SCN neurons simultaneously. Relative to standard electrophysiological approaches, they also allow for cellular recordings to be performed in a relatively noninvasive manner for many days in culture. Together with more traditional approaches, real-time imaging techniques provide excellent tools to investigate cellular clock function and network properties.

\section{The SCN network: greater than the sum of its parts}

It is now well established that the SCN contains multiple cellular clocks that interact with one another to form a functional network. As described above, individual SCN cells can express self-sustained circadian rhythms (Welsh et al. 1995, Herzog et al. 1998, Honma et al. 1998). Nevertheless, it is clear that SCN neurons are weaker clocks when isolated from one another. For instance, $\sim 60 \%$ of SCN neurons are competent oscillators when dispersed in low-density culture, but only $\sim 30 \%$ of neurons are rhythmic under conditions of complete isolation (Webb et al. 2009). Strikingly, this is much lower than that observed when SCN neurons are connected in the network, with $>90 \%$ of cells sustaining rhythms in a slice preparation. Further, coupled SCN neurons display rhythms that are more precise, higher amplitude, and more robust to perturbation and stochastic noise (Herzog et al. 2004, Abraham et al. 2010, Buhr et al. 2010). Remarkably, network interactions can even preserve cellular clock function when the molecular oscillator is crippled by genetic defects (Nakamura et al. 2002, Liu et al. 2007, Ko et al. 2010, Evans et al. 2012). This series of observations indicates that SCN neurons can keep time by themselves, but are more capable clocks when they receive signals from other cells in the network. Of note, this is not true for all types of clock cells. Fibroblasts are strong circadian oscillators that appear to depend very little on one another for sustaining cellular rhythms (Nagoshi et al. 2004, Leise et al. 2012). While this may be viewed as evidence that SCN neurons are 'weaker' clocks than fibroblasts, this is not necessarily the case. Fibroblast clocks may oscillate well as individual cells, but they lack network-level properties that can buffer them from clock gene mutations (Liu et al. 2007). By contrast, SCN neurons have strength in numbers because they influence and bolster one another.

Another key property of SCN neurons is that they are able to synchronize with one another. SCN neurons embedded within the network display well-coordinated rhythms both in vivo and in vitro. By contrast, $\mathrm{SCN}$ neurons that are dissociated 'run at different speeds' due to the expression of different period lengths (Welsh et al. 1995, Herzog et al. 1998, Honma et al. 1998). As a consequence, dissociated SCN neurons gradually lose synchrony with one another over time in culture. But SCN neurons remain synchronized when they are able to interact fully with one another. These results indicate that SCN neurons adopt a common period due to intercellular communication, which prevents loss of synchrony among SCN neurons. Studies of mutant SCN neurons likewise suggest that they interact with one another to determine overall period (Liu et al. 1997, Herzog et al. 1998, Low-Zeddies \& Takahashi 2001). Due to their ability to synchronize, SCN neurons remain coordinated as a population, maintain tissue-level rhythms, and send strong outputs to downstream tissues. Importantly, the coherence of SCN rhythms is a key determinant of behavioral and physiological rhythmicity (Ciarleglio et al. 2009). This is a property that appears to be unique to the SCN because most other types of cells appear unable to synchronize with one another (Yamazaki et al. 2000, Nagoshi et al. 2004, Welsh et al. 2004). Cellular clocks that lack communication would be expected to rely on SCN-controlled signals to maintain tissue coherence (Farnell et al. 2011). For example, fibroblasts are strong cellular oscillators, but they desynchronize and lose population-level rhythms (Welsh et al. 2004). Interestingly, it may be their strongly autonomous cellular clock that prevents fibroblasts from synchronizing with one another (Locke et al. 2008).

Lastly, network interactions influence the relative timing of neuronal activity to regulate the waveform of their collective rhythm. When embedded in the network,

Published by Bioscientifica Ltd. 
SCN neurons 'prefer' to adopt specific phase relationships with electrical and molecular rhythms that are slightly dispersed in time rather than occurring all at the same time (Quintero et al. 2003, Saeb-Parsy \& Dyball 2003, Yamaguchi et al. 2003, Hamada et al. 2004, Rohling et al. 2006, Yan et al. 2007, Evans et al. 2011, Myung et al. 2012, Brancaccio et al. 2013). This is not a random event; rather, there are clear regional phase differences that are reproducible and stereotyped across animals. Phase mapping analyses of PERIOD2::LUCIFERASE (PER2::LUC) expression in the murine SCN reveal several consistent patterns (Evans et al. 2011). First, the caudal SCN typically assumes an earlier phase than the rostral SCN. Also, there are fairly complex gradients of expression, with the dorsal SCN phase leading more central and ventral regions. These spatiotemporal arrangements are intrinsically regulated by the network itself (Quintero et al. 2003, Yamaguchi et al. 2003, Evans et al. 2011), and yet can be modulated markedly by environmental lighting conditions (reviewed in Meijer et al. 2012, Evans \& Gorman 2016).

In terms of environmental modulation of SCN temporal organization, one of the most studied contexts is seasonal changes in day length. Day length regulates the phase coherence of SCN neurons, with more clustered phases under short winter-like days than long summerlike days (Jagota et al. 2000, Hazlerigg et al. 2005, Inagaki et al. 2007, Naito et al. 2008, Evans et al. 2013, Myung et al. 2015). Temporal coherence of phase among SCN neurons influences the overall waveform of rhythms produced by the network, with longer duration of clock gene expression and electrical activity under long days. This photoperiodic encoding is determined largely by changes in SCN phase relationships rather than changes in cellular rhythms (Rohling et al. 2006, Brown \& Piggins 2009). Effectively, photoperiodic encoding by the SCN network alters the patterning of outputs transmitted under summer vs winter conditions. Seasonal changes in SCN outputs provide time of year information to downstream tissues to produce seasonal changes in behavior and physiology (Schaap et al. 2003, Inagaki et al. 2007). Thus, the SCN network is both a daily clock and an annual calendar.

In addition to its ecological significance, plasticity in SCN phase relationships can be exploited to test mechanisms of intercellular communication (Evans et al. 2013, 2015). In this approach, SCN neurons are desynchronized by light in vivo and then allowed to resynchronize in vitro, so that the process of network coupling can be tracked in real time. Specifically, very long day lengths reorganize the SCN network, so that it adopts a highly polarized state with two groups of SCN neurons cycling in antiphase. After release from these lighting conditions, SCN neurons within these two groups interact with one another and gradually resynchronize over the course of a week. Leveraging this form of network plasticity, the process of SCN coupling can be tracked in real time using an ex vivo slice preparation. By capturing the dynamic process of SCN communication, this analytical assay may provide a novel discovery tool for further defining the circuitry of the SCN network (Evans et al. 2013).

\section{SCN network organization: functional differences among neuronal subclasses}

The SCN contains local projection neurons that communicate with one another and with other hypothalamic structures (Abrahamson \& Moore 2001, Moore et al. 2002). The axons of many SCN neurons terminate within the nucleus itself, thus forming local circuit connections and/or collaterals from longer range projections. Nearly all SCN neurons produce $\beta$-aminobutyric acid (GABA), yet they can be categorized into distinct subgroups based on co-expression of different neuropeptides (Moore \& Speh 1993, Abrahamson \& Moore 2001). The SCN is typically subdivided into two spatially segregated compartments: the shell and the core (Moore $\&$ Silver 1998). These two compartments contain distinct subclasses of neurons that differ neurochemically (Fig. 3). The SCN shell contains a dense population of neurons that express arginine vasopressin (AVP), as well as other types of neurons. The SCN core contains a variety of subclasses, including neurons that express vasoactive intestinal polypeptide (VIP) or gastrin-releasing peptide (GRP). These subgroups have distinct developmental patterns (Antle et al. 2005b, Bedont \& Blackshaw 2015) and are thought to represent distinct subclasses with minimal overlap in neuropeptide expression. However, as the index of SCN peptides grows, it is becoming apparent that $\mathrm{SCN}$ neurons can co-express different peptides that may contribute to their functional activity (e.g. Geoghegan \& Carter 2008, Atkins et al. 2010, Drouyer et al. 2010, Hundahl et al. 2012, Lee et al. 2015). Although the shell-core scheme of the SCN network continues to be a convenient construct, it will likely morph to become more sophisticated as understanding of SCN circuitry increases (Morin 2007, 2012).

The expression and location of AVP and VIP neurons are consistent across mammalian species, but regional anatomy and chemoarchitecture can vary (Morin 2007, Cassone et al. 1988). For example, the SCN of rodents

Published by Bioscientifica Ltd. 
A
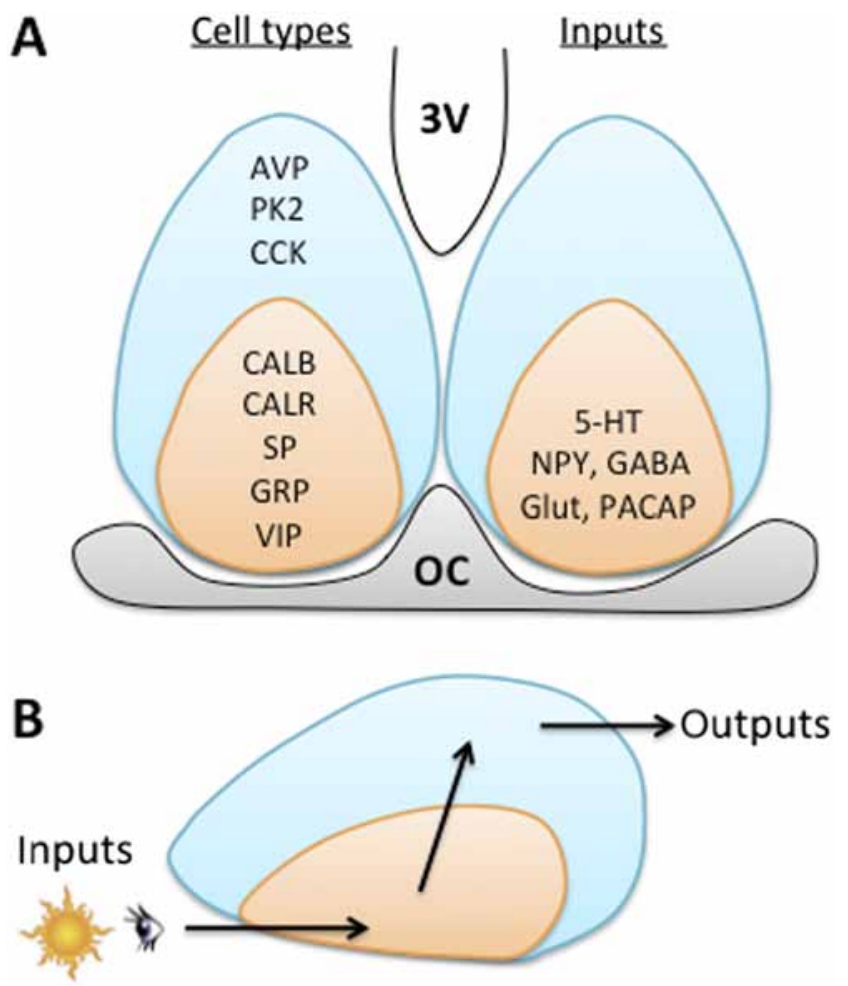

Figure 3

The SCN network is a heterogeneous population of cellular clocks. (A) Organization of the mouse SCN, illustrating the compartmentalization of cell types and inputs in the coronal plane. AVP, arginine vasopressin; $\mathrm{PK}$, prokineticin 2; CCK, cholecystokinin; CALB, calbindin; CALR, calretinin; SP, substance P; GRP, gastrin-releasing peptide; VIP, vasoactive intestinal polypeptide; 5 -HT, serotonin (from dorsal raphe); NPY, neuropeptide Y (from intergeniculate leaflet of the thalamus, which also releases GABA, neurotensin, and enkephalin), Glut, glutamate (from retina); PACAP, pituitary adenylate cyclase-activating polypeptide (from retina); $3 \mathrm{~V}$, third ventricle; OC, optic chiasm. (B) The shell-core model of the SCN network, representing how each compartment is thought to contribute to pacemaker function.

contains neurons that express calcium-binding proteins, but the location and specific proteins expressed differ among rodent species. In the Syrian hamster, calbindinexpressing SCN neurons form a spatially segregated subgroup densely packed into the central region of the core compartment. The mouse SCN contains both calbindin and calretinin neurons, with greatest expression within the core compartment. However, neither population forms a dense subnucleus. By contrast, calretinin neurons in the rat appear in the SCN shell rather than the SCN core. Another example of SCN variability across species is neuropeptide Y (NPY) expression. The rodent SCN does not produce NPY, but the human SCN does (Moore 1991). The consequence of species variation in SCN chemoarchitecture warrants further study given its potential influence on SCN function.
In addition to differences in neuropeptide expression, SCN neurons can be distinguished based on their response to afferent input. For instance, light exposure during the night typically increases SCN electrical activity and gene expression (i.e. C-fos, Period), but does so only in a subset of neurons (Meijer et al. 1986, Jiao et al. 1999, Aggelopoulos \& Meissl 2000, Schwartz et al. 2000, Hamada et al. 2001, Nakamura et al. 2004, Brown et al. 2011). Of those SCN neurons affected directly by retinal stimulation, some respond with sustained increases in electrical activity, some respond with phasic responses, and others are inhibited. Further, photoresponsive SCN neurons may be distinguished based on the source of retinal input they receive (Brown et al. 2011). Tract tracing studies suggest that there is a denser retinal projection to the SCN core than the SCN shell (Abrahamson \& Moore 2001, Lokshin et al. 2015), which maps onto functional differences in photic response. After light exposure, the SCN core displays changes in gene expression that precede those in the SCN shell (Silver et al. 1996, Dardente et al. 2002, Yan \& Okamura 2002, Yan \& Silver 2002, 2004, Kuhlman et al. 2003, Nagano et al. 2003). Regional differences in photic responsiveness have functional consequences that can influence how the network adjusts following changes in environmental lighting conditions. For instance, after simulated travel across time zones, the SCN core re-entrains faster than the SCN shell (Nagano et al. 2003, Albus et al. 2005, Nakamura et al. 2005, Davidson et al. 2009, Rohling et al. 2011, Sellix et al. 2012), and this form of light-driven desynchrony is thought to contribute to symptoms of jetlag. Moreover, regional patterning of afferent projections to the SCN is not unique to the retina, with inputs from the thalamus, pretectum, and median raphe also being densest in the SCN core (Fig. 3, for review, see Morin \& Allen 2006). Furthermore, the SCN shell may receive input from a distinct set of structures, at least in the rat (Moga \& Moore 1997, Leak \& Moore 2001). Future studies should test whether this is consistent across mammalian species given the potential implications.

SCN neurons can also be distinguished based on efferent projections. The SCN communicates with downstream targets using both synaptic and humoral signals (Mohawk \& Takahashi 2011). In the case of synaptic connections, the SCN innervates structures in the hypothalamus, thalamus, and forebrain (Watts 1991, Kalsbeek \& Buijs 2002), and these projections may originate from specific SCN regions. With regard to outputs from SCN neuronal subclasses, those originating from AVP and VIP neurons have been most extensively studied. AVP and VIP neurons often project to the same

Published by Bioscientifica Ltd 
target, but the relative patterning of innervation can be target-specific (Watts \& Swanson 1987, Abrahamson \& Moore 2001, Kalsbeek \& Buijs 2002). For instance, both AVP and VIP neurons in the murine SCN project to the paraventricular nucleus and the dorsomedial nucleus of the hypothalamus, but each target contains more AVP fibers than VIP fibers (Abrahamson \& Moore 2001). The functional roles of projections from distinct SCN regions are far from fully understood. Thus far, research indicates that both SCN compartments influence rhythms in downstream targets, yet there are differences in the role of outputs from different SCN regions (Yan et al. 2005, Zhou \& Cheng 2005, Lee et al. 2009, Schwartz et al. 2009, Kalsbeek et al. 2010, Butler et al. 2012, Smarr et al. 2012, Wotus et al. 2013, Evans et al. 2015). One emerging theme is that the SCN shell appears to set the phase of downstream tissues; however, both SCN shell and core neurons provide signals to downstream tissues that can influence their rhythms. The efferent projection patterns of distinct SCN subclasses should be revisited in future work given recent advances in cell-type-specific tract tracing (Callaway \& Luo 2015). A deeper understanding of this issue may provide insight into the functional role of outputs from different SCN subclasses.

Lastly, there is a rich body of work describing regional differences in SCN function. As mentioned above, SCN neurons display regional differences in the phase of electrical and molecular activities, which can be detected even within a chemically defined subclass (Hamada et al. 2004, Kalsbeek et al. 2006, Evans et al. 2011, Yoshikawa et al. 2015). Although the majority of SCN neurons tend to exhibit clustered phases of electrical and molecular activities, antiphase rhythms are expressed by subgroups of SCN neurons whose chemical identity remains ill defined (Nakamura et al. 2001, King et al. 2003, Lee et al. 2003). In addition, SCN neurons from distinct regions or peptidergic subclasses can exhibit different period length (Shinohara et al. 1995, Nakamura et al. 2001, Noguchi \& Watanabe 2008, Myung et al. 2012). Further, daily patterns of electrical activity can differ markedly among neuronal subgroups (Shibata et al. 1984, Jiao et al. 1999, Jobst \& Allen 2002, Saeb-Parsy \& Dyball 2003, Belle et al. 2009). This suggests that SCN neurons can oscillate with different properties, but the presence of cellular rhythms may not be universal among SCN neurons. Many studies examining the SCN network have found that photoresponsive neurons within the SCN core display a less rhythmic or arrhythmic phenotype (Jiao et al. 1999, Hamada et al. 2001, Jobst \& Allen 2002). However, recent work indicates that cellular rhythmicity is stochastic, not restricted to neurons of a particular peptidergic subgroup, and sustained by network interactions (Webb et al. 2009). This provides new insight, in that it suggests that there is no single subclass of 'pacemaker' neuron in the SCN network, and that cellular rhythmicity is strongly influenced by network connectivity rather than chemical phenotype.

In summary, $\mathrm{SCN}$ neurons in different regions of the network can be distinguished in many ways. The most common model of SCN organization highlights functional distinctions between its shell and core compartments. In this scheme, the SCN core contains first-order neurons that receive and process photic input. SCN core neurons display strong rhythms in light-induced responses, but electrical and molecular rhythms of these neurons may be low amplitude or nonexistent. Nevertheless, input transmitted from SCN core neurons is important for coordinating neurons in the rest of the network. In contrast, neurons in the SCN shell are strongly rhythmic and play a key role in transmitting daily outputs to downstream structures. Overall, there is utility in this linear model, but some key aspects of SCN circuitry remain unexplained. For example, if SCN core neurons are not different from SCN shell neurons when studied in isolation, what accounts for their differences when they are embedded in the network? If specific subclasses of SCN core neurons do indeed lack a strong molecular oscillator, how do they maintain circadian rhythms in photic responsiveness? Presumably, these observations reflect that molecular and photoresponsive rhythms of SCN core neurons are influenced by intercellular communication, but the relevant signals remain undefined. Additional work investigating SCN signaling is expected to expand the understanding of its circuitry.

\section{SCN coupling mechanisms}

SCN neurons communicate through multiple mechanisms and signaling factors (van den Pol \& Dudek 1993, Michel \& Colwell 2001, Aton \& Herzog 2005). An important role of synaptic signaling is based on observations that SCN neurons desynchronize when cultured with tetrodotoxin (TTX) to block $\mathrm{Na}^{+}$-dependent action potentials (Yamaguchi et al. 2003). However, there is also evidence that the SCN network can use other forms of coupling that do not depend on synaptic communication. For instance, SCN timekeeping can be maintained in the absence of $\mathrm{Na}^{+-}$ dependent action potentials and $\mathrm{Ca}^{+2}$-dependent synaptic transmission (Schwartz et al. 1987, Earnest et al. 1991,

Published by Bioscientifica Ltd. 
Schwartz 1991, Bouskila \& Dudek 1993, Dudek et al. 1993, Shibata \& Moore 1993). Further, circadian rhythms are maintained in some species in vivo under environmental conditions that severely compromise neuronal activity (Menaker 1961, Grahn et al. 1994). Further, the SCN displays metabolic rhythms at an embryonic age (Shibata \& Moore 1987, Reppert 1992) that precedes the completion of synaptogenesis (Bedont \& Blackshaw 2015). Collectively, this suggests that synaptic transmission is not the exclusive means by which SCN neurons can communicate with one another. Interestingly, functional studies indicate that SCN neurons can communicate through paracrine signaling (Maywood et al. 2011). In this work, co-cultured SCN slices were able to influence the rhythmic properties of one another even though they were unable to establish cross-slice synaptic connections. One potential mechanism driving this effect may be the nonsynaptic release of SCN neuropeptides from axons, dendrites, and somata (Castel et al. 1996). While it remains unclear which specific SCN neuropeptides are released at these sites, this form of communication may influence the function of neuronal networks (Ludwig \& Leng 2006, van den Pol 2012). In the section below, recent insight into the roles of different SCN coupling factors has been reviewed. In particular, much has been learned about the ways in which VIP, GABA, and AVP signaling influence SCN function. Nevertheless, it remains a challenge to fully map the neurochemical, temporal, and spatial properties of SCN circuits.

\section{Vasoactive intestinal polypeptide (VIP)}

Over the past decade, clear evidence has emerged that indicates VIP is important for synchronizing SCN neurons (Vosko et al. 2007, Harmar 2003). As described above, VIP is produced by a subset of SCN neurons located within the ventral SCN core, with functional evidence suggesting that there are at least two subclasses of VIP neurons in the rat (Kawamoto et al. 2003). VIP is expected to have pervasive effects because VIP+ fibers innervate nearly all SCN regions (Card et al. 1981, Card \& Moore 1984), and most SCN neurons express the VIP receptor, VPAC2 (Kalamatianos et al. 2004b, Kallo et al. 2004b, An et al. 2012). The influence of VIP signaling is expected to fluctuate daily since VIP and its receptor are expressed rhythmically in the SCN in vivo and in vitro (Takahashi et al. 1989, Glazer \& Gozes 1994, Duncan et al. 1995, Shinohara et al. 1995, Cagampang et al. 1998, Dardente et al. 2004). The VPAC2 receptor is a $\mathrm{G \alpha}_{\mathrm{s}}$-coupled receptor that activates adenylyl cyclase, cAMP, PKA, and
CRE-dependent transcription (Fig. 4A, Harmar et al. 1998, Couvineau \& Laburthe 2011). Given that Period genes are activated by CREB, this suggests that VIP will influence cellular rhythms in SCN neurons. As expected, VIP signaling alters SCN electrical and molecular activities in vivo and in vitro (Piggins et al. 1995, Nielsen et al. 2002, Cutler et al. 2003, Itri \& Colwell 2003, Pakhotin et al. 2006, Irwin \& Allen 2010, Kudo et al. 2013). Moreover, it can phase-shift other SCN neuropeptide rhythms, such as AVP release (Watanabe et al. 2000). Consistent with VPAC2 being a $G \alpha_{s}$-coupled receptor, the effects of VIP on SCN electrical and molecular rhythms depend on PKA signaling (Nielsen et al. 2002, Meyer-Spasche \& Piggins 2004, An et al. 2011). However, VIP-induced effects also require activation of other intracellular cascades (i.e., mitogen-activated protein kinase, phospholipase C), which indicates that other signaling mechanisms may be involved (Fig. 4A).

Interest in the role of VIP signaling was especially piqued when it was discovered that the loss of VIP signaling is able to compromise circadian rhythmicity. When studied under constant dark conditions, the majority of mice lacking the gene for VIP or its receptor display either arrhythmic locomotor patterns or lowamplitude rhythms with altered period (Harmar et al. 2002, Colwell et al. 2003, Aton et al. 2005, Ciarleglio et al. 2009). Arrhythmic Vip-deficient mice also display loss of rhythms in SCN electrical activity and gene expression due to the lack of network synchrony and a decrease in the number of SCN neurons able to maintain viable cellular rhythms (Aton et al. 2005, Maywood et al. 2006, Brown et al. 2007, Hughes et al. 2008, Ciarleglio et al. 2009). Importantly, SCN cellular rhythms and synchrony can be rescued in Vip knockout slices by daily application of a VPAC2 agonist (Aton et al. 2005). Loss of cellular rhythms and synchrony likewise occurs in wildtype SCN slices exposed to a VPAC2 antagonist (Brown et al. 2007, Evans et al. 2013), which suggests that the effects of VIP/VPAC2 deletion are not due to developmental abnormalities. Further, VIP signaling has important consequences for spatiotemporal arrangements of the SCN network, which involves intercellular communication triggered by $\mathrm{G}_{\mathrm{q}}$ signaling in VIP neurons (Brancaccio et al. 2013). Collectively, this work indicates that VIP is a local coupling factor that amplifies and entrains SCN neurons that are weak intrinsic oscillators. These effects are very important for maintaining cellular rhythms and synchronized network activity within the SCN network.

In addition to serving as a local coupling factor, VIP signaling also influences other processes. In particular, VIP

Published by Bioscientifica Ltd. 


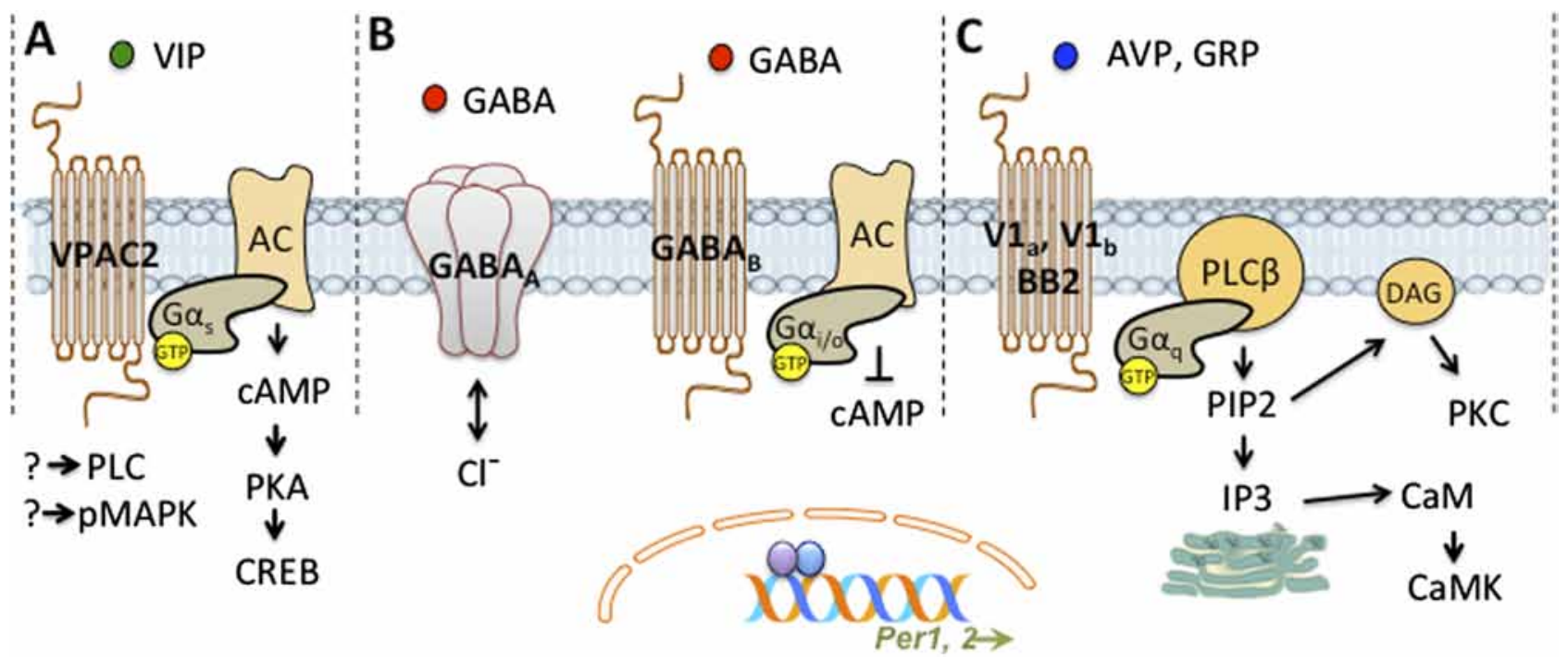

Figure 4

Intercellular signaling mechanisms that alter cellular activity and clock gene expression within SCN neurons. (A) SCN neurons express the VPAC2 receptor for VIP, which is a G-protein-coupled receptor with seven transmembrane domains. Upon VIP binding to VPAC2, G $\alpha_{s}$ activates adenylyl cyclase, cAMP, PKA, and CRE-dependent transcription. (B) Within the $S C N$, both $G A B A_{A}$ receptors and $G A B A_{B}$ receptors are expressed. GABA binding to the ionotropic $\mathrm{GABA}_{A}$ receptor allows for influx or efflux of $\mathrm{Cl}^{-}$, depending on $[\mathrm{Cl}-]_{i}$ By contrast, the metabotropic $\mathrm{GABA}_{B}$ receptor is coupled to $\mathrm{G} \alpha_{i / 0}$, which inhibits adenylyl cyclase. (C) The receptors for both AVP and GRP are $\mathrm{G}_{\alpha}$-coupled receptors that stimulate phospholipase C (PLC $\beta$ ), which in turn activates phosphatidylinositol 4,5-bisphosphate (PIP2) to cause diacyl glycerol (DAG)-mediated activation of protein kinase C (PKC) and inositol triphosphate (IP3)-induced release of intracellular calcium stores. Intracellular release of calcium activates calmodulin (CaM), which stimulates $\mathrm{Ca}^{2+1}$ calmodulindependent protein kinase (CaMK). Due to the expression of CRE-elements in Period genes, changes in the intracellular signaling cascades illustrated in A-C can alter the function of the molecular clock.

is involved in photic signaling (Shen et al. 2000, Colwell et al. 2003, Kuhlman et al. 2003, Hughes et al. 2004, Dragich et al. 2010, Lucassen et al. 2012, An et al. 2013), and light influences VIP expression in the SCN (Duncan et al. 1995, Shinohara \& Inouye 1995, Isobe \& Nishino 1998, Smith \& Canal 2009, Francl et al. 2010). Deficits in VIP signaling cause abnormal responses to light, with one result being an unusual responsiveness to light during the day. Furthermore, loss of VIP causes disruptions in a wide variety of physiological processes, including cardiovascular function, metabolism, and reproduction (Shimizu et al. 1996, Bechtold et al. 2008, Sheward et al. 2010, Hannibal et al. 2011, Schroeder et al. 2011, Loh et al. 2014). This indicates that VIP signaling is important for maintaining endocrine function, which could be due to its role in the SCN network itself and/or its role as an output signal to downstream tissues (van der Beek et al. 1993, Kalsbeek et al. 1993, Gerhold et al. 2001, Egli et al. 2004, Kallo et al. 2004b, Gerhold \& Wise 2006, Loh et al. 2011, Fahrenkrug et al. 2012). Also, age- and sexrelated differences in VIP expression may influence changes in the strength and robustness of circadian function (Zhou et al. 1995, Kawakami et al. 1997, Krajnak et al. 1998a,b, Kallo et al. 2004a, Mahoney et al. 2009). Thus,
VIP signaling is an important modulator whose absence has widespread consequences for behavior and physiology. There continues to be a need to define the properties and mechanisms of VIP signaling to better understand how it regulates clock function at the cellular, network, and systems levels. For instance, recent work demonstrates that VIP can desynchronize the phase of SCN neurons if given at the wrong time or at high doses (An et al. 2013, Ananthasubramaniam et al. 2014). This suggests that VIP expression is tightly regulated within the SCN network. Of interest, 4E-BP1 has been identified recently as a molecular repressor of Vip mRNA translation (Cao et al. 2013). Future studies are expected to provide additional insight into the temporal and spatial features of VIP signaling, as well as modulatory mechanisms.

\section{$\gamma$-aminobutyric acid (GABA)}

Since it was first reported that nearly all SCN neurons express GABA, it has been suspected that this neurotransmitter regulates SCN communication. The SCN displays a high density of GABA terminals and cells (van den Pol \& Tsujimoto 1985, Okamura et al. 1989, Decavel \& Van den Pol 1990, Moore \& Speh 1993,

Published by Bioscientifica Ltd. 
Huhman et al. 1996, Castel \& Morris 2000, Abrahamson \& Moore 2001). Receptors for GABA include both ionotropic $G_{A B A}$ receptors and metabotropic $G_{A B A}$ receptors coupled to $\mathrm{G} \alpha_{\mathrm{i} / \mathrm{o}}$ (Fig. 4B, Bormann 2000), with both being expressed in the SCN (Gao et al. 1995, O'Hara et al. 1995, Naum et al. 2001, Belenky et al. 2003, 2008). As with other SCN factors, daily rhythms in GABA signaling are evident in the SCN, and these rhythms can be modulated by light exposure (Aguilar-Roblero et al. 1993, Huhman et al. 1996, Naum et al. 2001, Itri et al. 2004). Consistent with this anatomical work, SCN neurons are sensitive to GABA signaling (Liou et al. 1990, Mason et al. 1991, Gillespie et al. 1997, 1999, Jiang et al. 1997b, Strecker et al. 1997, Biggs \& Prosser 1998, Cardinali \& Golombek 1998, Mintz et al. 2002, Ehlen et al. 2008). Collectively, these studies indicate that GABA regulates SCN neuronal activity, modulates photic signaling, and serves as an output signal to downstream tissues (Wang et al. 2003). For modulation of photic signaling, an important role has been demonstrated for both $\mathrm{GABA}_{\mathrm{A}}$ and $\mathrm{GABA}_{\mathrm{B}}$ receptors (Gillespie et al. 1997, Biggs \& Prosser 1998, Belenky et al. 2003, Novak et al. 2004, Ehlen \& Paul 2009). By contrast, $\mathrm{GABA}_{\mathrm{A}}$ receptor signaling is thought to be the strongest local regulator of SCN network activity (Kim \& Dudek 1992, Shimura et al. 1996, Strecker et al. 1997, Albus et al. 2005, Fan et al. 2015). Over the last two decades, work has revealed surprising ways in which GABA can modulate SCN function.

One of the first surprises discovered about GABA signaling in the SCN concerns the polarity of responses to this neurotransmitter. GABA is typically defined as an inhibitory neurotransmitter; however, GABA can depolarize and increase intracellular calcium concentration in SCN neurons (Wagner et al. 1997, Choi et al. 2008, Irwin \& Allen 2009). Although excitatory GABAergic responses are not always observed (Bos \& Mirmiran 1993, Dudek et al. 1993, Gribkoff et al. 1999), this may stem at least in part from spatial or temporal differences in recordings performed in different laboratories (De Jeu \& Pennartz 2002, Albus et al. 2005, Choi et al. 2008, Ikeda et al. 2013, Alamilla et al. 2014, DeWoskin et al. 2015). Indeed, the SCN displays regional differences in the expression of the chloride co-transporters (Belenky et al. 2008, 2010, Choi et al. 2008) that determine chloride reversal potential (Vogt 2015). Adding to this complexity, it has been demonstrated recently that the polarity of GABA responses in the SCN is influenced by the duration of daily light exposure (Farajnia et al. 2014, Myung et al. 2015). This may have great relevance for the ability of the
SCN to serve as an annual calendar, and firmly places the SCN on the growing list of mature neural networks that exhibit plasticity in the polarity of GABA responses (Marty \& Llano 2005).

Given that the nature of SCN responses to GABA remain unclear, it should come as little surprise that the precise role of GABA in SCN coupling has proven difficult to define. Early work demonstrated that dissociated SCN neurons exposed to GABA will synchronize their electrical rhythms via $\mathrm{GABA}_{\mathrm{A}}$ signaling (Liu \& Reppert 2000, Shirakawa et al. 2000). Additional studies further indicated that $\mathrm{GABA}_{\mathrm{A}}$ signaling is involved in the transfer of resetting information from the SCN core to the SCN shell (Albus et al. 2005, Han et al. 2012). However, GABA receptor antagonists do not desynchronize SCN neurons in vitro (Aton et al. 2006). These results came as a surprise because they run counter to the hypothesis that GABA acts as a coupling factor. Recent work has provided some insight into these conflicting findings. $\mathrm{GABA}_{\mathrm{A}}$ signaling does influence SCN coupling, but surprisingly it destabilizes phase relationships of SCN neurons (Evans et al. 2013, Freeman et al. 2013, DeWoskin et al. 2015, Myung et al. 2015). Normally, this effect of $G_{A B A}$ signaling is hard to detect because VIP signaling is a potent synchronizing agent. But in the absence of VIP, SCN neurons desynchronize due to $\mathrm{GABA}_{\mathrm{A}}$ signaling (Evans et al. 2013, Freeman et al. 2013). In fact, antagonism of $\mathrm{GABA}_{\mathrm{A}}$ signaling will 'fix' a Vip KO slice and prevent desynchrony from occurring. This indicates that the loss of synchrony that emerges during VIP deficiency is not due to 'passive' desynchrony caused by cellular period differences but rather 'active' desynchronizing responses elicited by GABA signaling. This provides us with a new view into SCN circuitry because it indicates that some SCN signaling mechanisms promote synchronization, while others may cause desynchronization. This also reveals that SCN coupling factors may be arranged into pairs that oppose one another's effects. Building on this theme of interactive coupling mechanisms, $\mathrm{GABA}_{\mathrm{A}}$ signaling can interact with VIP signaling in either an antagonistic or cooperative manner depending on the state of the network (Evans et al. 2013), which may account for earlier work demonstrating synchronizing effects (Liu \& Reppert 2000, Shirakawa et al. 2000, Albus et al. 2005, Han et al. 2012). Together with previous work, this strongly suggests that the functional role of a coupling mechanism can change based on the experience, history, or age of the animal (Evans et al. 2013, Bedont et al. 2014, Wang et al. 2014).

Published by Bioscientifica Ltd. 


\section{Arginine vasopressin (AVP)}

Although AVP has been traditionally viewed more as an SCN output signal, a more direct role in network synchronization has been suggested recently. AVP is rhythmically expressed both in vivo and in vitro (Cassone et al. 1988, Sukhov et al. 1993, Shinohara et al. 1998, Dardente et al. 2004, Van der Veen et al. 2005, Miller et al. 2006, Noguchi \& Watanabe 2008, Mahoney et al. 2009, Yoshikawa et al. 2015). Of the three known AVP receptors, $\mathrm{V}_{1 \mathrm{a}}$ (V1) and $\mathrm{V}_{1 \mathrm{~b}}$ (V3) are expressed within the SCN (Kalamatianos et al. 2004a, Li et al. 2009), which are both $\mathrm{G}_{\mathrm{q}}$-coupled receptors that stimulate phospholipase C to cause DAG-mediated activation of PKC and IP3induced mobilization of intracellular calcium (Fig. 4C, Maybauer et al. 2008). Although AVP was one of the first SCN neuropeptides to be discovered, it was deemed not necessary for circadian rhythms based on work in rats with a spontaneous loss-of-function mutation (Groblewski et al. 1981, Boer et al. 1998). Further work, however, revealed that these rats display lower amplitude rhythms of sleep, melatonin release, and corticosterone (Schroder et al. 1988, Brown \& Nunez 1989, Wideman et al. 2000), and this led to the suggestion that AVP was mostly an important output signal (Jin et al. 1999, Tousson \& Meissl 2004). In support of a network role, however, AVP neurons project locally within the SCN itself (Castel et al. 1990, Romijn et al. 1997) and exogenous AVP is able to regulate the cellular activity of SCN neurons (Liou \& Albers 1989, Mihai et al. 1994, Ingram et al. 1998). However, it was unclear whether these responses actually produced functional consequences because AVP application in vitro or in vivo does not phase-shift SCN rhythms. Nevertheless, recent work has revealed that AVP is able to influence the function of the SCN network. $\mathrm{V}_{1 \mathrm{a}}$ and $\mathrm{V}_{1 \mathrm{~b}}$ receptor knockout mice display a pronounced circadian phenotype, in that they are resistant to jetlag and re-entrain almost instantly following a shift in the light:dark cycle (Yamaguchi et al. 2013). Wildtype mice receiving AVP receptor antagonists directed to the SCN likewise shift quickly, thus discounting a developmental basis of this effect. Rapid recovery following simulated jetlag is also observed in mice lacking Bmal1 in AVP neurons, which can be reversed by SCN-specific rescue of molecular clock function (Mieda et al. 2015). Collectively, this work suggests that AVP signaling is involved in setting the pace of re-entrainment. It has been proposed that the loss of AVP signaling causes a change in SCN coupling that allows the entire network to shift rapidly to the new time zone. Consistent with this, application of AVP can synchronize SCN neurons collected from mice deficient in VIP signaling (Maywood et al. 2011). Further work testing the specific role of AVP signaling in SCN coupling is warranted.

\section{Gastrin-releasing peptide (GRP)}

The potential role of GRP in SCN coupling remains to be determined, although there is clear evidence that GRP signaling is involved in photic processing. GRP is rhythmically expressed in the SCN and modulated by light (Shinohara et al. 1993, Dardente et al. 2004, Lee et al. 2013). The GRP receptor, also known as the bombesin 2 (BB2) receptor, is likewise rhythmically expressed within the SCN in a manner influenced by light exposure (Karatsoreos et al. 2006). Like the AVP receptor, BB2 is a $\mathrm{G} \alpha_{\mathrm{q}}$-coupled receptor (Fig. 4C, Jensen et al. 2008). GRP neurons within the $\mathrm{SCN}$ receive retinal input that induces cellular responses (Dardente et al. 2002, Lesauter et al. 2011). Further, GRP can phase-shift SCN rhythms in vitro and locomotor rhythms in vivo in a pattern similar to those induced by light and VIP (Piggins et al. 1995, Gillespie et al. 1997, McArthur et al. 2000, Aida et al. 2002, Piggins et al. 2005, Antle et al. 2005a, Gamble et al. 2007, Biello 2009). These effects of GRP are dependent on BB2 receptor signaling, CREB-dependent transcription, clock gene activation, and changes in fast delayed rectifier potassium currents (Aida et al. 2002, Piggins et al. 2005, Gamble et al. $2007,2011)$. However, the role of GRP may not be limited to photic signaling because GRP can enhance cellular rhythms in SCN slices collected from mice deficient in VIP signaling (Brown et al. 2005, Maywood et al. 2006, 2011). Further, cellular rhythmicity is attenuated by a BB2 receptor antagonist, but only when applied in the absence of VIP signaling (Brown et al. 2005). Together with the work on GABA described above, this suggests that VIP is a very strong modulator of $\mathrm{SCN}$ cellular rhythms that may mask the effects of other signaling mechanisms.

\section{Other neuroactive substances}

In addition to these well-studied subgroups, there are likely novel subclasses of SCN neurons that play a role in network coupling. The SCN produces dozens of signaling factors, and the number of recognized SCN peptides continues to increase (van den Pol \& Tsujimoto 1985, Lee et al. 2013, 2015). A recent study demonstrated that SCN network function is regulated by neuromedin $S$, which is an SCN peptide produced by both AVP and VIP neurons

Published by Bioscientifica Ltd. 
(Lee et al. 2015). Also, a forward peptidomics screen identified little SAS as a novel peptide produced in the SCN core that relays photic signals independent of VIPor GRP-dependent signaling (Atkins et al. 2010). Another interesting development is that intra-SCN glutamatergic signaling may play a role in coupling the left and right SCN (Michel et al. 2013), and yet glutamate is not expressed by SCN neurons (Strecker et al. 1997). Communication between the left and right SCN likely differs from that coupling neurons within each SCN (Bouskila \& Dudek 1993), and additional studies may shed new light on mechanisms mediating this coupling. Overall, this work highlights that the SCN remains a complex structure, and it is likely that additional coupling signals will be identified in the future.

\section{Nonsynaptic interactions}

One early hypothesis posited a role of local electric field effects produced by changes in the membrane potential of adjacent cells. Ephaptic interactions produced by electrical field potentials in dendrites can synchronize electrical activity in the mammalian neocortex, but it is unlikely that this mechanism couples oscillators within the SCN given its nonlaminar organization (Van den Pol 1980, van Esseveldt et al. 2000). Nevertheless, functional and anatomical evidence suggests that SCN neurons can communicate through nonsynaptic release of neuropeptides (Castel et al. 1996, Maywood et al. 2011). Moreover, electrotonic communication through low-resistance gap junctions may influence SCN coupling (Jiang et al. 1997a, Colwell 2000, Jobst et al. 2004, Long et al. 2005). Gap junctions are channels that allow the exchange of small molecules between neurons and/or glia in close apposition (Bennett et al. 1991, Rash et al. 2000, 2001, Connors \& Long 2004). Gap junctions can be found in both SCN neurons and glia, with the diffusion of labeled molecules (i.e. dye coupling) occurring mostly between homotypic cells located in the same SCN compartment (Jiang et al. 1997a, Colwell 2000). Studies using paired intracellular recordings and dye coupling suggest that electrical coupling varies as a function of circadian phase (Colwell 2000, Long et al. 2005), which suggests that communication through gap junctions is not a passive process but one that is actively regulated in a dynamic fashion. Further evidence that gap junctions likely influence SCN function stems from pharmacological experiments demonstrating that SCN electrical rhythms become broader, arrhythmic, or bimodal after octanol or halothane application (Prosser et al. 1994, Shinohara et al. 2000a,b, Shirakawa et al. 2001). These specific changes in waveform are thought to reflect changes in SCN phase relationships caused by altered coupling, although this has yet to be tested directly. Further, the cellular location of these gap junctions remains unclear since these pharmacological inhibitors would be expected to affect both neurons and glia, as well as producing offtarget effects. A specific role for neuronal gap junctions is indicated by work demonstrating that SCN electrical coupling is dependent on the expression of the neuronspecific gap junction protein connexin36 (Long et al. 2005). Signaling through these gap junctions is thought to infleunce circadian behavior because mice lacking connexin36 display reduced amplitude of locomotor rhythms under constant darkness (Long et al. 2005). Another factor that may modulate circadian behavior via gap junction signaling is the expression of the polysialylated form of neural cell adhesion molecule (Lee et al. 1995, Glass et al. 2003), although this protein is also involved in synaptic transmission. This work suggests that gap junctions influence SCN function, but additional studies are needed to delineate their precise role.

\section{Astrocytes}

While most circadian research has focused on the functional properties of SCN neurons, the SCN also contains glial cells (Guldner 1983). SCN astrocytes can be detected by labeling glial fibrillary acidic protein (GFAP), which displays a daily rhythm that is modulated by light (Lavialle \& Serviere 1993, Moriya et al. 2000, Gerics et al. 2006, Becquet et al. 2008, Lindley et al. 2008, Canal et al. 2009). Like other cell types, astrocytes are intrinsic oscillators that display daily rhythms in metabolic function (Schwartz \& Gainer 1977, van den Pol et al. 1992, Lavialle \& Serviere 1993, Womac et al. 2009, Burkeen et al. 2011) and clock gene/protein expression (van den Pol et al. 1992, Prolo et al. 2005, Cheng et al. 2009, Yagita et al. 2010, Duhart et al. 2013). The available evidence points to several ways in which SCN glia and neurons interact (Jackson 2011); however, the precise role of glia in the SCN network is not well characterized. In general, astrocytes provide physical support, release pro-survival factors, influence synaptic clearance, and produce gliotransmitters that interact with presynaptic and postsynaptic receptors (Faissner et al. 2010). Anatomical and functional evidence suggests that SCN astrocytes may influence light-induced resetting by http://joe.endocrinology-journals.org DOI: 10.1530/JOE-16-0054
(C) 2016 Society for Endocrinology Printed in Great Britain
Published by Bioscientifica Ltd. 
regulating glutamate release from retinal terminals (van den Pol et al. 1992, Lavaille \& Serviere 1995, Tamada et al. 1998, Moriya et al. 2000, Lavialle et al. 2001, Girardet et al. 2010). Interestingly, VIP and AVP neurons in the SCN core and shell compartments display differences in daily rhythms of glial coverage of dendrites, with higher coverage of VIP and AVP neurons during the night and day, respectively (Becquet et al. 2008). This suggests that SCN glia may differentially regulate signaling to these two subpopulations across the circadian cycle. Consistent with a glial role in SCN photic responses and/or interneuronal coupling, mice that have a mutation in GFAP have altered locomotor activity rhythms in LL (Moriya et al. 2000). More direct evidence for glial involvement in SCN coupling is provided by work demonstrating that SCN electrical rhythms become bimodal in the presence of the glial metabolism antagonist, fluorocitrate (Prosser et al. 1994). These changes in the waveform of SCN electrical rhythms are thought to be due to altered communication among SCN neuronal subpopulations (Wang et al. 2014), which could be tested further with real-time imaging techniques. Communication between SCN neurons and astrocytes is likely bidirectional since damped rhythms in astrocytes are enhanced by co-culture with SCN explants, but not cortical explants (Prolo et al. 2005). Further, VIP influences the phase and amplitude of astrocyte rhythms in a dose-dependent manner (Marpegan et al. 2009). Collectively, this work suggests that SCN astrocytes and neurons interact with one another, and future studies are expected to clarify the functional consequences of this relationship.

\section{Conclusions}

In many ways, mapping the circuitry of the SCN remains a challenge. Defining the specific role of any given signaling mechanism can be complicated given that multiple processes interact and modulate one another (Shinohara et al. 2000b, Itri et al. 2004, Haas et al. 2011, Wang et al. 2014). In addition, it remains a challenge to separate the role of a given neuromodulator in mediating intranetwork coupling from its role in processing input and transmitting output. Despite the difficulty in addressing these issues, it remains critical to address how SCN cells integrate the various signals provided by other cell types in the network. The combinatorial effects of SCN coupling factors have yet to be systemically investigated, although some work has addressed this issue in the context of photic signaling (Albers et al. 1991, Piggins et al. 1995). It is likely that future technological advances will prove critical for achieving a deeper understanding of SCN circuitry. Going forward, it will be important to define the precise cellular location of receptors for putative coupling factors. Further, whether these receptors are co-expressed spatially and temporally on specific subclasses of SCN neurons should be addressed in future work. Given the potential for rhythms in each component of SCN signaling (e.g. signal release, receptor expression, physical connectivity, and astrocyte function), advanced techniques for imaging cellular connections and responses will continue to be essential for making progress in this area.

\section{Declaration of interest}

The author declares that there is no conflict of interest that could be perceived as prejudicing the impartiality of this review.

\section{Funding}

Funding support from the NIH (R01NS091234) and the Whitehall Foundation (2014-12-65) is acknowledged.

\section{References}

Abraham U, Granada AE, Westermark PO, Heine M, Kramer A \& Herzel H 2010 Coupling governs entrainment range of circadian clocks. Molecular Systems Biology 6 438. (doi:10.1038/msb.2010.92)

Abrahamson EE \& Moore RY 2001 Suprachiasmatic nucleus in the mouse: retinal innervation, intrinsic organization and efferent projections. Brain Research 916 172-191. (doi:10.1016/S0006-8993(01)02890-6)

Aggelopoulos NC \& Meissl H 2000 Responses of neurones of the rat suprachiasmatic nucleus to retinal illumination under photopic and scotopic conditions. Journal of Physiology 523 211-222. (doi:10.1111/j.1469-7793.2000.t01-1-00211.x)

Aguilar-Roblero R, Verduzco-Carbajal L, Rodriguez C, MendezFranco J, Moran J \& de la Mora MP 1993 Circadian rhythmicity in the GABAergic system in the suprachiasmatic nuclei of the rat. Neuroscience Letters 157 199-202. (doi:10.1016/0304-3940(93)90736-5)

Aida R, Moriya T, Araki M, Akiyama M, Wada K, Wada E \& Shibata S 2002 Gastrin-releasing peptide mediates photic entrainable signals to dorsal subsets of suprachiasmatic nucleus via induction of Period gene in mice. Molecular Pharmacology 61 26-34. (doi:10.1124/mol.61.1.26)

Alamilla J, Perez-Burgos A, Quinto D \& Aguilar-Roblero R 2014 Circadian modulation of the $\mathrm{Cl}(-)$ equilibrium potential in the rat suprachiasmatic nuclei. BioMed Research International 2014424982. (doi:10.1155/2014/424982)

Albers HE, Liou SY, Stopa EG \& Zoeller RT 1991 Interaction of colocalized neuropeptides: functional significance in the circadian timing system. Journal of Neuroscience 11 846-851.

Albus H, Vansteensel MJ, Michel S, Block GD \& Meijer JH 2005 A GABAergic mechanism is necessary for coupling dissociable ventral and dorsal regional oscillators within the circadian clock. Current Biology 15 886-893. (doi:10.1016/j.cub.2005.03.051)

An S, Irwin RP, Allen CN, Tsai CA \& Herzog ED 2011 Vasoactive intestinal polypeptide requires parallel changes in adenylate cyclase and phospholipase $\mathrm{C}$ to entrain circadian rhythms to a predictable
(C) 2016 Society for Endocrinology Printed in Great Britain 
phase. Journal of Neurophysiology 105 2289-2296. (doi:10.1152/ jn.00966.2010)

An S, Tsai C, Ronecker J, Bayly A \& Herzog ED 2012 Spatiotemporal distribution of vasoactive intestinal polypeptide receptor 2 in mouse suprachiasmatic nucleus. Journal of Comparative Neurology $\mathbf{5 2 0}$ 2730-2741. (doi:10.1002/cne.23078)

An S, Harang R, Meeker K, Granados-Fuentes D, Tsai CA, Mazuski C, Kim J, Doyle FJ III, Petzold LR \& Herzog ED 2013 A neuropeptide speeds circadian entrainment by reducing intercellular synchrony. PNAS 110 E4355-E4361. (doi:10.1073/pnas.1307088110)

Ananthasubramaniam B, Herzog ED \& Herzel H 2014 Timing of neuropeptide coupling determines synchrony and entrainment in the mammalian circadian clock. PLoS Computational Biology 10 e1003565. (doi:10.1371/journal.pcbi.1003565)

Antle MC \& Silver R 2005 Orchestrating time: arrangements of the brain circadian clock. Trends in Neurosciences 28 145-151. (doi:10.1016/j. tins.2005.01.003)

Antle MC, Kriegsfeld LJ \& Silver R 2005a Signaling within the master clock of the brain: localized activation of mitogen-activated protein kinase by gastrin-releasing peptide. Journal of Neuroscience $\mathbf{2 5}$ 2447-2454.

Antle MC, LeSauter J \& Silver R 2005b Neurogenesis and ontogeny of specific cell phenotypes within the hamster suprachiasmatic nucleus. Developmental Brain Research 157 8-18. (doi:10.1016/j. devbrainres.2005.02.017)

Atkins N Jr, Mitchell JW, Romanova EV, Morgan DJ, Cominski TP, Ecker JL, Pintar JE, Sweedler JV \& Gillette MU 2010 Circadian integration of glutamatergic signals by little SAAS in novel suprachiasmatic circuits. PLOS ONE 5 e12612. (doi:10.1371/journal. pone.0012612)

Aton SJ \& Herzog ED 2005 Come together, right...now: synchronization of rhythms in a mammalian circadian clock. Neuron 48 531-534.

Aton SJ, Colwell CS, Harmar AJ, Waschek J \& Herzog ED 2005 Vasoactive intestinal polypeptide mediates circadian rhythmicity and synchrony in mammalian clock neurons. Nature Neuroscience $\mathbf{8}$ 476-483.

Aton SJ, Huettner JE, Straume M \& Herzog ED 2006 GABA and Gi/o differentially control circadian rhythms and synchrony in clock neurons. PNAS 103 19188-19193. (doi:10.1073/pnas.0607466103)

Bechtold DA, Brown TM, Luckman SM \& Piggins HD 2008 Metabolic rhythm abnormalities in mice lacking VIP-VPAC2 signaling. American Journal of Physiology: Regulatory, Integrative and Comparative Physiology 294 R344-R351.

Becquet D, Girardet C, Guillaumond F, Francois-Bellan AM \& Bosler O 2008 Ultrastructural plasticity in the rat suprachiasmatic nucleus. Possible involvement in clock entrainment. Glia 56 294-305. (doi:10.1002/glia.20613)

Bedont JL \& Blackshaw S 2015 Constructing the suprachiasmatic nucleus: a watchmaker's perspective on the central clockworks. Frontiers in Systems Neuroscience 9 74. (doi:10.3389/fnsys.2015.00074)

Bedont JL, LeGates TA, Slat EA, Byerly MS, Wang H, Hu J, Rupp AC, Qian J, Wong GW, Herzog ED, et al. 2014 Lhx1 controls terminal differentiation and circadian function of the suprachiasmatic nucleus. Cell Reports 7 609-622. (doi:10.1016/j.celrep.2014.03.060)

Belenky MA, Sagiv N, Fritschy JM \& Yarom Y 2003 Presynaptic and postsynaptic $\mathrm{GABA}_{\mathrm{A}}$ receptors in rat suprachiasmatic nucleus. Neuroscience 118 909-923. (doi:10.1016/S0306-4522(03)00062-9)

Belenky MA, Yarom Y \& Pickard GE 2008 Heterogeneous expression of gamma-aminobutyric acid and gamma-aminobutyric acid-associated receptors and transporters in the rat suprachiasmatic nucleus. Journal of Comparative Neurology 506 708-732. (doi:10.1002/cne.21553)

Belenky MA, Sollars PJ, Mount DB, Alper SL, Yarom Y \& Pickard GE 2010 Cell-type specific distribution of chloride transporters in the rat suprachiasmatic nucleus. Neuroscience 165 1519-1537. (doi:10.1016/j. neuroscience.2009.11.040)
Belle MD, Diekman CO, Forger DB \& Piggins HD 2009 Daily electrical silencing in the mammalian circadian clock. Science 326 281-284. (doi:10.1126/science.1169657)

Bennett MV, Barrio LC, Bargiello TA, Spray DC, Hertzberg E \& Saez JC 1991 Gap junctions: new tools, new answers, new questions. Neuron 6 305-320. (doi:10.1016/0896-6273(91)90241-Q)

Biello SM 2009 Circadian clock resetting in the mouse changes with age. Age 31 293-303. (doi:10.1007/s11357-009-9102-7)

Biggs KR \& Prosser RA 1998 GABA $_{B}$ receptor stimulation phase-shifts the mammalian circadian clock in vitro. Brain Research 807 250-254. (doi:10.1016/S0006-8993(98)00820-8)

Boer GJ, van Esseveldt LE \& Rietveld WJ 1998 Cellular requirements of suprachiasmatic nucleus transplants for restoration of circadian rhythm. Chronobiology International 15 551-566. (doi:10.3109/07420529808998707)

Bormann J 2000 The 'ABC' of GABA receptors. Trends in Pharmacological Sciences 21 16-19. (doi:10.1016/S0165-6147(99)01413-3)

Bos NP \& Mirmiran M 1993 Effects of excitatory and inhibitory amino acids on neuronal discharges in the cultured suprachiasmatic nucleus. Brain Research Bulletin 31 67-72. (doi:10.1016/0361-9230(93)90012-Z)

Bouskila Y \& Dudek FE 1993 Neuronal synchronization without calciumdependent synaptic transmission in the hypothalamus. PNAS 90 3207-3210. (doi:10.1073/pnas.90.8.3207)

Brancaccio M, Maywood ES, Chesham JE, Loudon AS \& Hastings MH $2013 \mathrm{~A} \mathrm{G}_{\mathrm{q}}-\mathrm{Ca}^{2+}$ axis controls circuit-level encoding of circadian time in the suprachiasmatic nucleus. Neuron 78 714-728. (doi:10.1016/j. neuron.2013.03.011)

Brown MH \& Nunez AA 1989 Vasopressin-deficient rats show a reduced amplitude of the circadian sleep rhythm. Physiology \& Behavior 46 759-762.

Brown TM \& Piggins HD 2007 Electrophysiology of the suprachiasmatic circadian clock. Progress in Neurobiology 82 229-255. (doi:10.1016/j. pneurobio.2007.05.002)

Brown TM \& Piggins HD 2009 Spatiotemporal heterogeneity in the electrical activity of suprachiasmatic nuclei neurons and their response to photoperiod. Journal of Biological Rhythms 24 44-54. (doi:10.1177/0748730408327918)

Brown TM, Hughes AT \& Piggins HD 2005 Gastrin-releasing peptide promotes suprachiasmatic nuclei cellular rhythmicity in the absence of vasoactive intestinal polypeptide-VPAC2 receptor signaling. Journal of Neuroscience 25 11155-11164. (doi:10.1523/ JNEUROSCI.3821-05.2005)

Brown TM, Colwell CS, Waschek JA \& Piggins HD 2007 Disrupted neuronal activity rhythms in the suprachiasmatic nuclei of vasoactive intestinal polypeptide-deficient mice. Journal of Neurophysiology 97 2553-2558. (doi:10.1152/jn.01206.2006)

Brown TM, Wynne J, Piggins HD \& Lucas RJ 2011 Multiple hypothalamic cell populations encoding distinct visual information. Journal of Physiology 589 1173-1194. (doi:10.1113/jphysiol.2010.199877)

Buhr ED \& Takahashi JS 2013 Molecular components of the mammalian circadian clock. Handbook of Experimental Pharmacology 217 3-27. (doi:10.1007/978-3-642-25950-0)

Buhr ED, Yoo SH \& Takahashi JS 2010 Temperature as a universal resetting cue for mammalian circadian oscillators. Science $\mathbf{3 3 0}$ 379-385. (doi:10.1126/science.1195262)

Burkeen JF, Womac AD, Earnest DJ \& Zoran MJ 2011 Mitochondrial calcium signaling mediates rhythmic extracellular ATP accumulation in suprachiasmatic nucleus astrocytes. Journal of Neuroscience $\mathbf{3 1}$ 8432-8440. (doi:10.1523/JNEUROSCI.6576-10.2011)

Butler MP, Rainbow MN, Rodriguez E, Lyon SM \& Silver R 2012 Twelve-hour days in the brain and behavior of split hamsters. European Journal of Neuroscience 36 2556-2566. (doi:10.1111/j.14609568.2012.08166.x)

Cagampang FRA, Sheward WJ, Harmar AJ, Piggins HD \& Coen CW 1998 Circadian changes in the expression of vasoactive intestinal peptide http://joe.endocrinology-journals.org

DOI: $10.1530 / \mathrm{JOE}-16-0054$
(C) 2016 Society for Endocrinology Printed in Great Britain
Published by Bioscientifica Ltd. 
2 receptor $\mathrm{mRNA}$ in the rat suprachiasmatic nuclei. Molecular Brain Research 54 108-112. (doi:10.1016/S0169-328X(97)00327-6)

Callaway EM \& Luo L 2015 Monosynaptic circuit tracing with glycoprotein-deleted rabies viruses. Journal of Neuroscience $\mathbf{3 5}$ 8979-8985. (doi:10.1523/JNEUROSCI.0409-15.2015)

Canal MM, Mohammed NM \& Rodriguez JJ 2009 Early programming of astrocyte organization in the mouse suprachiasmatic nuclei by light. Chronobiology International 26 1545-1558. (doi:10.3109/07420520903398542)

Cao R, Robinson B, Xu H, Gkogkas C, Khoutorsky A, Alain T, Yanagiya A, Nevarko T, Liu AC, Amir S, et al. 2013 Translational control of entrainment and synchrony of the suprachiasmatic circadian clock by mTOR/4E-BP1 signaling. Neuron 79 712-724. (doi:10.1016/j. neuron.2013.06.026)

Card JP \& Moore RY 1984 The suprachiasmatic nucleus of the golden hamster: immunohistochemical analysis of cell and fiber distribution. Neuroscience 13 415-431. (doi:10.1016/0306-4522(84)90240-9)

Card JP, Brecha N, Karten HJ \& Moore RY 1981 Immunocytochemical localization of vasoactive intestinal polypeptide-containing cells and processes in the suprachiasmatic nucleus of the rat: light and electron microscopic analysis. Journal of Neuroscience $\mathbf{1}$ 1289-1303.

Cardinali DP \& Golombek DA 1998 The rhythmic GABAergic system. Neurochemical Research 23 607-614. (doi:10.1023/A:1022426519297)

Cassone VM, Speh JC, Card JP \& Moore RY 1988 Comparative anatomy of the mammalian hypothalamic suprachiasmatic nucleus. Journal of Biological Rhythms 3 71-91. (doi:10.1177/074873048800300106)

Castel M \& Morris JF 2000 Morphological heterogeneity of the GABAergic network in the suprachiasmatic nucleus, the brain's circadian pacemaker. Journal of Anatomy 196 1-13. (doi:10.1046/ j.1469-7580.2000.19610001.x)

Castel M, Feinstein N, Cohen S \& Harari N 1990 Vasopressinergic innervation of the mouse suprachiasmatic nucleus: an immunoelectron microscopic analysis. Journal of Comparative Neurology 298 172-187. (doi:10.1002/cne.902980204)

Castel M, Morris J \& Belenky M 1996 Non-synaptic and dendritic exocytosis from dense-cored vesicles in the suprachiasmatic nucleus. Neuroreport 7 543-547. (doi:10.1097/00001756-199601310-00040)

Cheng HY, Alvarez-Saavedra M, Dziema H, Choi YS, Li A \& Obrietan K 2009 Segregation of expression of mPeriod gene homologs in neurons and glia: possible divergent roles of mPeriod 1 and mPeriod 2 in the brain. Human Molecular Genetics 18 3110-3124. (doi:10.1093/hmg/ ddp252)

Choi HJ, Lee CJ, Schroeder A, Kim YS, Jung SH, Kim JS, Kim do Y, Son EJ, Han HC, Hong SK, et al. 2008 Excitatory actions of GABA in the suprachiasmatic nucleus. Journal of Neuroscience 28 5450-5459. (doi:10.1523/JNEUROSCI.5750-07.2008)

Ciarleglio CM, Gamble KL, Axley JC, Strauss BR, Cohen JY, Colwell CS \& McMahon DG 2009 Population encoding by circadian clock neurons organizes circadian behavior. Journal of Neuroscience 29 1670-1676. (doi:10.1523/JNEUROSCI.3801-08.2009)

Colwell CS 2000 Rhythmic coupling among cells in the suprachiasmatic nucleus. Journal of Neurobiology 43 379-388. (doi:10.1002/10974695(20000615)43:4<379::aid-neu6>3.0.co;2-0)

Colwell CS, Michel S, Itri J, Rodriguez W, Tam J, Lelievre V, Hu Z, Liu X \& Waschek JA 2003 Disrupted circadian rhythms in VIP- and PHIdeficient mice. American Journal of Physiology: Regulatory, Integrative and Comparative Physiology 285 R939-R949.

Connors BW \& Long MA 2004 Electrical synapses in the mammalian brain. Annual Review of Neuroscience 27 393-418. (doi:10.1146/ annurev.neuro.26.041002.131128)

Couvineau A \& Laburthe M 2011 VPAC receptors: structure, molecular pharmacology and interaction with accessory proteins. British Journal of Pharmacology 166 42-50. (doi:10.1111/j.1476-5381.2011.01676.x)

Cutler DJ, Haraura M, Reed HE, Shen S, Sheward WJ, Morrison CF, Marston HM, Harmar AJ \& Piggins HD 2003 The mouse VPAC2 receptor confers suprachiasmatic nuclei cellular rhythmicity and responsiveness to vasoactive intestinal polypeptide in vitro. European Journal of Neuroscience 17 197-204. (doi:10.1046/j.14609568.2003.02425.x)

Czeisler CA \& Klerman EB 1999 Circadian and sleep-dependent regulation of hormone release in humans. Recent Progress in Hormone Research 54 97-130.

Dardente H, Poirel VJ, Klosen P, Pevet P \& Masson-Pevet M 2002 Per and neuropeptide expression in the rat suprachiasmatic nuclei: compartmentalization and differential cellular induction by light. Brain Research 958 261-271. (doi:10.1016/S0006-8993(02)03563-1)

Dardente H, Menet JS, Challet E, Tournier BB, Pevet P \& MassonPevet M 2004 Daily and circadian expression of neuropeptides in the suprachiasmatic nuclei of nocturnal and diurnal rodents. Brain Research. Molecular Brain Research 124 143-151. (doi:10.1016/j. molbrainres.2004.01.010)

Davidson AJ, Castanon-Cervantes O, Leise TL, Molyneux PC \& Harrington ME 2009 Visualizing jet lag in the mouse suprachiasmatic nucleus and peripheral circadian timing system. European Journal of Neuroscience 29 171-180. (doi:10.1111/j.14609568.2008.06534.x)

De Jeu M \& Pennartz C 2002 Circadian modulation of GABA function in the rat suprachiasmatic nucleus: excitatory effects during the night phase. Journal of Neurophysiology 87 834-844.

Decavel C \& Van den Pol AN 1990 GABA: a dominant neurotransmitter in the hypothalamus. Journal of Comparative Neurology $\mathbf{3 0 2}$ 1019-1037. (doi:10.1002/cne.903020423)

DeWoskin D, Myung J, Belle MD, Piggins HD, Takumi T \& Forger DB 2015 Distinct roles for GABA across multiple timescales in mammalian circadian timekeeping. PNAS 112 E3911-E3919. (doi:10.1073/pnas.1420753112)

Dragich JM, Loh DH, Wang LM, Vosko AM, Kudo T, Nakamura TJ, Odom IH, Tateyama S, Hagopian A, Waschek JA, et al. 2010 The role of the neuropeptides PACAP and VIP in the photic regulation of gene expression in the suprachiasmatic nucleus. European Journal of Neuroscience 31 864-875. (doi:10.1111/j.1460-9568.2010.07119.x)

Drouyer E, LeSauter J, Hernandez AL \& Silver R 2010 Specializations of gastrin-releasing peptide cells of the mouse suprachiasmatic nucleus. Journal of Comparative Neurology 518 1249-1263. (doi:10.1002/ cne.22272)

Dudek FE, Kim YI \& Bouskila Y 1993 Electrophysiology of the suprachiasmatic nucleus: synaptic transmission, membrane properties, and neuronal synchronization. Journal of Biological Rhythms 8 (Supplement) S33-S37.

Duhart JM, Leone MJ, Paladino N, Evans JA, Castanon-Cervantes O, Davidson AJ \& Golombek DA 2013 Suprachiasmatic astrocytes modulate the circadian clock in response to TNF-alpha. Journal of Immunology 191 4656-4664. (doi:10.4049/jimmunol.1300450)

Duncan MJ, Cheng X \& Heller KS 1995 Photoperiodic exposure and time of day modulate the expression of arginine vasopressin mRNA and vasoactive intestinal peptide mRNA in the suprachiasmatic nuclei of Siberian hamsters. Brain Research. Molecular Brain Research 32 181-186. (doi:10.1016/0169-328X(95)00072-Z)

Earnest DJ, Digiorgio SM \& Sladek CD 1991 Effects of tetrodotoxin on the circadian pacemaker mechanism in suprachiasmatic explants in vitro. Brain Research Bulletin 26 677-682. (doi:10.1016/03619230(91)90160-L)

Egli M, Bertram R, Sellix MT \& Freeman ME 2004 Rhythmic secretion of prolactin in rats: action of oxytocin coordinated by vasoactive intestinal polypeptide of suprachiasmatic nucleus origin. Endocrinology 145 3386-3394. (doi:10.1210/en.2003-1710)

Ehlen JC \& Paul KN 2009 Regulation of light's action in the mammalian circadian clock: role of the extrasynaptic $\mathrm{GABA}_{\mathrm{A}}$ receptor. American Journal of Physiology: Regulatory, Integrative and Comparative Physiology 296 R1606-R1612. (doi:10.1152/ajpregu.90878.2008)

Ehlen JC, Novak CM, Karom MC, Gamble KL \& Albers HE 2008 Interactions of $\mathrm{GABA}_{\mathrm{A}}$ receptor activation and light on Period mRNA

Published by Bioscientifica Ltd. 
expression in the suprachiasmatic nucleus. Journal of Biological Rhythms 23 16-25. (doi:10.1177/0748730407310785)

Enoki R, Kuroda S, Ono D, Hasan MT, Ueda T, Honma S \& Honma K 2012 Topological specificity and hierarchical network of the circadian calcium rhythm in the suprachiasmatic nucleus. PNAS 109 21498-21503. (doi:10.1073/pnas.1214415110)

Evans JA \& Gorman MR 2016 In synch but not in step: Circadian clock circuits regulating plasticity in daily rhythms. Neuroscience $\mathbf{3 2 0}$ 259-290. (doi:10.1016/j.neuroscience.2016.01.072)

Evans JA, Leise TL, Castanon-Cervantes O \& Davidson AJ 2011 Intrinsic regulation of spatiotemporal organization within the suprachiasmatic nucleus. PLoS ONE 6 e15869. (doi:10.1371/journal.pone.0015869)

Evans JA, Pan H, Liu AC \& Welsh DK 2012 Cry1\% circadian rhythmicity depends on SCN intercellular coupling. Journal of Biological Rhythms 27 443-452. (doi:10.1177/0748730412461246)

Evans JA, Leise TL, Castanon-Cervantes O \& Davidson AJ 2013 Dynamic interactions mediated by nonredundant signaling mechanisms couple circadian clock neurons. Neuron 80 973-983. (doi:10.1016/j. neuron.2013.08.022)

Evans JA, Suen TC, Callif BL, Mitchell AS, Castanon-Cervantes O, Baker KM, Kloehn I, Baba K, Teubner BJ, Ehlen JC, et al. 2015 Shell neurons of the master circadian clock coordinate the phase of tissue clocks throughout the brain and body. BMC Biology 1343. (doi:10.1186/s12915-015-0157-x)

Fahrenkrug J, Georg B, Hannibal J \& Jorgensen HL 2012 Altered rhythm of adrenal clock genes, StAR and serum corticosterone in VIP receptor 2-deficient mice. Journal of Molecular Neuroscience 48 584-596.

Faissner A, Pyka M, Geissler M, Sobik T, Frischknecht R, Gundelfinger ED \& Seidenbecher C 2010 Contributions of astrocytes to synapse formation and maturation - potential functions of the perisynaptic extracellular matrix. Brain Research Reviews 63 26-38. (doi:10.1016/j. brainresrev.2010.01.001)

Fan J, Zeng H, Olson DP, Huber KM, Gibson JR \& Takahashi JS 2015 Vasoactive intestinal polypeptide (VIP)-expressing neurons in the suprachiasmatic nucleus provide sparse GABAergic outputs to local neurons with circadian regulation occurring distal to the opening of postsynaptic GABAA ionotropic receptors. Journal of Neuroscience $\mathbf{3 5}$ 1905-1920. (doi:10.1523/JNEUROSCI.2661-14.2015)

Farajnia S, van Westering TL, Meijer JH \& Michel S 2014 Seasonal induction of GABAergic excitation in the central mammalian clock. PNAS 111 9627-9632. (doi:10.1073/pnas.1319820111)

Farnell YF, Shende VR, Neuendorff N, Allen GC \& Earnest DJ 2011 Immortalized cell lines for real-time analysis of circadian pacemaker and peripheral oscillator properties. European Journal of Neuroscience 33 1533-1540. (doi:10.1111/j.1460-9568.2011.07629.x)

Francl JM, Kaur G \& Glass JD 2010 Regulation of vasoactive intestinal polypeptide release in the suprachiasmatic nucleus circadian clock. Neuroreport 21 1055-1059. (doi:10.1097/WNR.0b013e32833fcba4)

Freeman GM Jr, Krock RM, Aton SJ, Thaben P \& Herzog ED 2013 GABA networks destabilize genetic oscillations in the circadian pacemaker. Neuron 78 799-806. (doi:10.1016/j.neuron.2013.04.003)

Gamble KL, Allen GC, Zhou T \& McMahon DG 2007 Gastrin-releasing peptide mediates light-like resetting of the suprachiasmatic nucleus circadian pacemaker through cAMP response element-binding protein and Per1 activation. Journal of Neuroscience 27 12078-12087. (doi:10.1523/JNEUROSCI.1109-07.2007)

Gamble KL, Kudo T, Colwell CS \& McMahon DG 2011 Gastrin-releasing peptide modulates fast delayed rectifier potassium current in Per1expressing SCN neurons. Journal of Biological Rhythms 26 99-106. (doi:10.1177/0748730410396678)

Gao B, Fritschy JM \& Moore RY 1995 GABA $_{\mathrm{A}}$-receptor subunit composition in the circadian timing system. Brain Research 700 142-156. (doi:10.1016/0006-8993(95)00944-L)

Gavrila A, Peng CK, Chan JL, Mietus JE, Goldberger AL \& Mantzoros CS 2003 Diurnal and ultradian dynamics of serum adiponectin in healthy men: comparison with leptin, circulating soluble leptin receptor, and cortisol patterns. Journal of Clinical Endocrinology \& Metabolism 88 2838-2843.

Geoghegan D \& Carter DA 2008 A novel site of adult doublecortin expression: neuropeptide neurons within the suprachiasmatic nucleus circadian clock. BMC Neuroscience 9 2. (doi:10.1186/1471-2202-9-2)

Gerhold LM \& Wise PM 2006 Vasoactive intestinal polypeptide regulates dynamic changes in astrocyte morphometry: impact on gonadotropin-releasing hormone neurons. Endocrinology 147 2197-2202. (doi:10.1210/en.2005-1262)

Gerhold LM, Horvath TL \& Freeman ME 2001 Vasoactive intestinal peptide fibers innervate neuroendocrine dopaminergic neurons. Brain Research 919 48-56. (doi:10.1016/S0006-8993(01)02993-6)

Gerics B, Szalay F \& Hajos F 2006 Glial fibrillary acidic protein immunoreactivity in the rat suprachiasmatic nucleus: circadian changes and their seasonal dependence. Journal of Anatomy 209 231-237. (doi:10.1111/j.1469-7580.2006.00593.x)

Gillespie CF, Mintz EM, Marvel CL, Huhman KL \& Albers HE 1997 $\operatorname{GABA}(\mathrm{A})$ and $\mathrm{GABA}(\mathrm{B})$ agonists and antagonists alter the phaseshifting effects of light when microinjected into the suprachiasmatic region. Brain Research 759 181-189. (doi:10.1016/S00068993(97)00235-7)

Gillespie CF, Van Der Beek EM, Mintz EM, Mickley NC, Jasnow AM, Huhman KL \& Albers HE 1999 GABAergic regulation of light-induced c-Fos immunoreactivity within the suprachiasmatic nucleus. Journal of Comparative Neurology 411 683-692. (doi:10.1002/(sici)10969861(19990906)411:4<683::aid-cne12>3.0.co;2-j)

Girardet C, Becquet D, Blanchard MP, Francois-Bellan AM \& Bosler O 2010 Neuroglial and synaptic rearrangements associated with photic entrainment of the circadian clock in the suprachiasmatic nucleus. European Journal of Neuroscience 32 2133-2142. (doi:10.1111/j.14609568.2011.07712.x)

Glass JD, Watanabe M, Fedorkova L, Shen H, Ungers G \& Rutishauser U 2003 Dynamic regulation of polysialylated neural cell adhesion molecule in the suprachiasmatic nucleus. Neuroscience 117 203-211. (doi:10.1016/S0306-4522(02)00817-5)

Glazer R \& Gozes I 1994 Diurnal oscillation in vasoactive intestinal peptide gene expression independent of environmental light entraining. Brain Research 644 164-167. (doi:10.1016/00068993(94)90360-3)

Grahn DA, Miller JD, Houng VS \& Heller HC 1994 Persistence of circadian rhythmicity in hibernating ground squirrels. American Journal of Physiology 266 R1251-R1258.

Gribkoff VK, Pieschl RL, Wisialowski TA, Park WK, Strecker GJ, de Jeu MT, Pennartz CM \& Dudek FE 1999 A reexamination of the role of GABA in the mammalian suprachiasmatic nucleus. Journal of Biological Rhythms 14 126-130. (doi:10.1177/074873099129000515)

Groblewski TA, Nunez AA \& Gold RM 1981 Circadian rhythms in vasopressin deficient rats. Brain Research Bulletin 6 125-130. (doi:10.1016/S0361-9230(81)80036-6)

Guldner FH 1983 Numbers of neurons and astroglial cells in the suprachiasmatic nucleus of male and female rats. Experimental Brain Research 50 373-376.

Haas JS, Zavala B \& Landisman CE 2011 Activity-dependent long-term depression of electrical synapses. Science 334 389-393. (doi:10.1126/ science.1207502)

Hamada T, LeSauter J, Venuti JM \& Silver R 2001 Expression of Period genes: rhythmic and nonrhythmic compartments of the suprachiasmatic nucleus pacemaker. Journal of Neuroscience $\mathbf{2 1}$ 7742-7750.

Hamada T, Antle MC \& Silver R 2004 Temporal and spatial expression patterns of canonical clock genes and clock-controlled genes in the suprachiasmatic nucleus. European Journal of Neuroscience 19 1741-1748. (doi:10.1111/j.1460-9568.2004.03275.x)

Han S, Yu FH, Schwartz MD, Linton JD, Bosma MM, Hurley JB, Catterall WA \& de la Iglesia HO $2012 \mathrm{Na}(\mathrm{V}) 1.1$ channels are critical for intercellular communication in the suprachiasmatic nucleus and

Published by Bioscientifica Ltd. 
for normal circadian rhythms. PNAS 109 E368-E377. (doi:10.1073/ pnas.1115729109)

Hannibal J, Hsiung HM \& Fahrenkrug J 2011 Temporal phasing of locomotor activity, heart rate rhythmicity, and core body temperature is disrupted in VIP receptor 2-deficient mice. American Journal of Physiology - Regulatory, Integrative and Comparative Physiology 300 R519-R530.

Harmar AJ 2003 An essential role for peptidergic signalling in the control of circadian rhythms in the suprachiasmatic nuclei. Journal of Neuroendocrinology 15 335-338. (doi:10.1046/j.13652826.2003.01005.x)

Harmar AJ, Arimura A, Gozes I, Journot L, Laburthe M, Pisegna JR, Rawlings SR, Robberecht P, Said SI, Sreedharan SP, et al. 1998 International union of pharmacology. XVIII. Nomenclature of receptors for vasoactive intestinal peptide and pituitary adenylate cyclase-activating polypeptide. Pharmacological Reviews 50 265-270.

Harmar AJ, Marston HM, Shen S, Spratt C, West KM, Sheward WJ, Morrison CF, Dorin JR, Piggins HD, Reubi JC, et al. 2002 The VPAC(2) receptor is essential for circadian function in the mouse suprachiasmatic nuclei. Cell 109 497-508. (doi:10.1016/S00928674(02)00736-5)

Hazlerigg DG, Ebling FJ \& Johnston JD 2005 Photoperiod differentially regulates gene expression rhythms in the rostral and caudal SCN. Current Biology 15 R449-R450.

Herzog ED, Takahashi JS \& Block GD 1998 Clock controls circadian period in isolated suprachiasmatic nucleus neurons. Nature Neuroscience 1 708-713. (doi:10.1038/3708)

Herzog ED, Aton SJ, Numano R, Sakaki Y \& Tei H 2004 Temporal precision in the mammalian circadian system: a reliable clock from less reliable neurons. Journal of Biological Rhythms 19 35-46. (doi:10.1177/0748730403260776)

Honma S, Shirakawa T, Katsuno Y, Namihira M \& Honma K 1998 Circadian periods of single suprachiasmatic neurons in rats. Neuroscience Letters 250 157-160. (doi:10.1016/S03043940(98)00464-9)

Hughes AT, Fahey B, Cutler DJ, Coogan AN \& Piggins HD 2004 Aberrant gating of photic input to the suprachiasmatic circadian pacemaker of mice lacking the VPAC2 receptor. Journal of Neuroscience 243522 3526. (doi:10.1523/JNEUROSCI.5345-03.2004)

Hughes AT, Guilding C, Lennox L, Samuels RE, McMahon DG \& Piggins HD 2008 Live imaging of altered Period 1 expression in the suprachiasmatic nuclei of Vipr2\% mice. Journal of Neurochemistry 106 1646-1657. (doi:10.1111/j.1471-4159.2008.05520.x)

Huhman KL, Hennessey AC \& Albers HE 1996 Rhythms of glutamic acid decarboxylase mRNA in the suprachiasmatic nucleus. Journal of Biological Rhythms 11 311-316. (doi:10.1177/074873049601100404)

Hundahl CA, Fahrenkrug J, Hay-Schmidt A, Georg B, Faltoft B \& Hannibal J 2012 Circadian behaviour in neuroglobin deficient mice. PLOS ONE 7 e34462. (doi:10.1371/journal.pone.0034462)

Ikeda Y, Kumagai H, Skach A, Sato M \& Yanagisawa M 2013 Modulation of circadian glucocorticoid oscillation via adrenal opioidCXCR7 signaling alters emotional behavior. Cell 155 1323-1336. (doi:10.1016/j.cell.2013.10.052)

Inagaki N, Honma S, Ono D, Tanahashi Y \& Honma K 2007 Separate oscillating cell groups in mouse suprachiasmatic nucleus couple photoperiodically to the onset and end of daily activity. PNAS 104 7664-7669. (doi:10.1073/pnas.0607713104)

Ingram CD, Ciobanu R, Coculescu IL, Tanasescu R, Coculescu M \& Mihai R 1998 Vasopressin neurotransmission and the control of circadian rhythms in the suprachiasmatic nucleus. Progress in Brain Research 119 351-364.

Irwin RP \& Allen CN 2009 GABAergic signaling induces divergent neuronal $\mathrm{Ca}^{2+}$ responses in the suprachiasmatic nucleus network. European Journal of Neuroscience 30 1462-1475. (doi:10.1111/j.14609568.2009.06944.x)
Irwin RP \& Allen CN 2010 Neuropeptide-mediated calcium signaling in the suprachiasmatic nucleus network. European Journal of Neuroscience 32 1497-1506. (doi:10.1111/j.1460-9568.2010.07411.x)

Irwin RP \& Allen CN 2013 Simultaneous electrophysiological recording and calcium imaging of suprachiasmatic nucleus neurons. Journal of Visualized Experiments 82 50794. (doi:10.3791/50794)

Isobe Y \& Nishino H 1998 AVP rhythm in the suprachiasmatic nucleus in relation to locomotor activity under constant light. Peptides 19 827-832. (doi:10.1016/S0196-9781(98)00021-7)

Itri J \& Colwell CS 2003 Regulation of inhibitory synaptic transmission by vasoactive intestinal peptide (VIP) in the mouse suprachiasmatic nucleus. Journal of Neurophysiology 90 1589-1597. (doi:10.1152/ jn.00332.2003)

Itri J, Michel S, Waschek JA \& Colwell CS 2004 Circadian rhythm in inhibitory synaptic transmission in the mouse suprachiasmatic nucleus. Journal of Neurophysiology 92 311-319. (doi:10.1152/ jn.01078.2003)

Jackson FR 2011 Glial cell modulation of circadian rhythms. Glia 59 1341-1350. (doi:10.1002/glia.21097)

Jagota A, de la Iglesia HO \& Schwartz WJ 2000 Morning and evening circadian oscillations in the suprachiasmatic nucleus in vitro. Nature Neuroscience 3 372-376. (doi:10.1038/73943)

Jensen RT, Battey JF, Spindel ER \& Benya RV 2008 International union of pharmacology. LXVIII. Mammalian bombesin receptors: nomenclature, distribution, pharmacology, signaling, and functions in normal and disease states. Pharmacological Reviews 60 1-42. (doi:10.1124/pr.107.07108)

Jiang Z-G, Yang Y-Q \& Allen CN 1997 a Tracer and electrical coupling of rat suprachiasmatic nucleus neurons. Neuroscience 77 1059-1066.

Jiang ZG, Yang Y, Liu ZP \& Allen CN 1997b Membrane properties and synaptic inputs of suprachiasmatic nucleus neurons in rat brain slices. Journal of Physiology 499 141-159.

Jiao YY, Lee TM \& Rusak B 1999 Photic responses of suprachiasmatic area neurons in diurnal degus (Octodon degus) and nocturnal rats (Rattus norvegicus). Brain Research 817 93-103. (doi:10.1016/S00068993(98)01218-9)

Jin X, Shearman LP, Weaver DR, Zylka MJ, de Vries GJ \& Reppert SM 1999 A molecular mechanism regulating rhythmic output from the suprachiasmatic circadian clock. Cell 96 57-68. (doi:10.1016/S00928674(00)80959-9)

Jobst EE \& Allen CN 2002 Calbindin neurons in the hamster suprachiasmatic nucleus do not exhibit a circadian variation in spontaneous firing rate. European Journal of Neuroscience $\mathbf{1 6}$ 2469-2474. (doi:10.1046/j.1460-9568.2002.02309.x)

Jobst EE, Robinson DW \& Allen CN 2004 Potential pathways for intercellular communication within the calbindin subnucleus of the hamster suprachiasmatic nucleus. Neuroscience 123 87-99. (doi:10.1016/j.neuroscience.2003.08.059)

Kalamatianos T, Kallo I \& Coen CW 2004a Ageing and the diurnal expression of the mRNAs for vasopressin and for the V1a and V1b vasopressin receptors in the suprachiasmatic nucleus of male rats. Journal of Neuroendocrinology 16 493-501.

Kalamatianos T, Kallo I, Piggins HD \& Coen CW 2004b Expression of VIP and/or PACAP receptor mRNA in peptide synthesizing cells within the suprachiasmatic nucleus of the rat and in its efferent target sites. Journal of Comparative Neurology 475 19-35.

Kallo I, Kalamatianos T, Piggins HD \& Coen CW 2004a Ageing and the diurnal expression of mRNAs for vasoactive intestinal peptide and for the VPAC2 and PAC1 receptors in the suprachiasmatic nucleus of male rats. Journal of Neuroendocrinology 16 758-766.

Kallo I, Kalamatianos T, Wiltshire N, Shen S, Sheward WJ, Harmar AJ \& Coen CW 2004b Transgenic approach reveals expression of the VPAC2 receptor in phenotypically defined neurons in the mouse suprachiasmatic nucleus and in its efferent target sites. European Journal of Neuroscience 19 2201-2211. http://joe.endocrinology-journals.org

DOI: $10.1530 / J O E-16-0054$
(C) 2016 Society for Endocrinology Printed in Great Britain
Published by Bioscientifica Ltd. 
Kalsbeek A \& Buijs RM 2002 Output pathways of the mammalian suprachiasmatic nucleus: coding circadian time by transmitter selection and specific targeting. Cell and Tissue Research 309 109-118. (doi:10.1007/s00441-002-0577-0)

Kalsbeek A, Teclemariam-Mesbah R \& Pevet P 1993 Efferent projections of the suprachiasmatic nucleus in the golden hamster (Mesocricetus auratus). Journal of Comparative Neurology 332 293-314. (doi:10.1002/ cne.903320304

Kalsbeek A, Perreau-Lenz S \& Buijs RM 2006 A network of (autonomic) clock outputs. Chronobiology International 23 521-535. (doi:10.1080/07420520600651073)

Kalsbeek A, Fliers E, Hofman MA, Swaab DF \& Buijs RM 2010 Vasopressin and the output of the hypothalamic biological clock. Journal of Neuroendocrinology 22 362-372. (doi:10.1111/j.13652826.2010.01956.x)

Karatsoreos IN, Romeo RD, McEwen BS \& Silver R 2006 Diurnal regulation of the gastrin-releasing peptide receptor in the mouse circadian clock. European Journal of Neuroscience 23 1047-1053. (doi:10.1111/j.1460-9568.2006.04633.x)

Kawakami F, Okamura H, Tamada Y, Maebayashi Y, Fukui K \& Ibata Y 1997 Loss of day-night differences in VIP mRNA levels in the suprachiasmatic nucleus of aged rats. Neuroscience Letters 222 99-102. (doi:10.1016/S0304-3940(97)13355-9)

Kawamoto K, Nagano M, Kanda F, Chihara K, Shigeyoshi Y \& Okamura H 2003 Two types of VIP neuronal components in rat suprachiasmatic nucleus. Journal of Neuroscience Research 74 852-857. (doi:10.1002/ jnr.10751)

Kim YI \& Dudek FE 1992 Intracellular electrophysiological study of suprachiasmatic nucleus neurons in rodents: inhibitory synaptic mechanisms. Journal of Physiology $\mathbf{4 5 8}$ 247-260. (doi:10.1113/ jphysiol.1992.sp019416)

King VM, Chahad-Ehlers S, Shen S, Harmar AJ, Maywood ES \& Hastings MH 2003 A hVIPR transgene as a novel tool for the analysis of circadian function in the mouse suprachiasmatic nucleus. European Journal of Neuroscience 17 822-832. (doi:10.1046/j.14609568.2003.02487.x)

Klein DC, Moore RY \& Reppert SM Eds 1991 Suprachiasmatic Nucleus: The Mind's Clock. New York, NY, USA: University Oxford Press.

Ko CH, Yamada YR, Welsh DK, Buhr ED, Liu AC, Zhang EE, Ralph MR, Kay SA, Forger DB \& Takahashi JS 2010 Emergence of noise-induced oscillations in the central circadian pacemaker. PLoS Biology 8 e1000513. (doi:10.1371/journal.pbio.1000513)

Koutkia P, Schurgin S, Berry J, Breu J, Lee BS, Klibanski A \& Grinspoon S 2005 Reciprocal changes in endogenous ghrelin and growth hormone during fasting in healthy women. American Journal of Physiology: Endocrinology and Metabolism 289 E814-E822.

Krajnak K, Kashon ML, Rosewell KL \& Wise PM 1998a Aging alters the rhythmic expression of vasoactive intestinal polypeptide mRNA but not arginine vasopressin mRNA in the suprachiasmatic nuclei of female rats. Journal of Neuroscience 18 4767-4774.

Krajnak K, Kashon ML, Rosewell KL \& Wise PM 1998b Sex differences in the daily rhythm of vasoactive intestinal polypeptide but not arginine vasopressin messenger ribonucleic acid in the suprachiasmatic nuclei. Endocrinology 139 4189-4196.

Kudo T, Tahara Y, Gamble KL, McMahon DG, Block GD \& Colwell CS 2013 Vasoactive intestinal peptide produces long-lasting changes in neural activity in the suprachiasmatic nucleus. Journal of Neurophysiology 110 1097-1106. (doi:10.1152/jn.00114.2013)

Kuhlman SJ 2007 Biological rhythms workshop IB: neurophysiology of SCN pacemaker function. Cold Spring Harbor Symposia on Quantitative Biology 72 21-33. (doi:10.1101/sqb.2007.72.061)

Kuhlman SJ, Quintero JE \& McMahon DG 2000 GFP fluorescence reports Period 1 circadian gene regulation in the mammalian biological clock. Neuroreport 11 1479-1482. (doi:10.1097/00001756-200005150-00023)

Kuhlman SJ, Silver R, Le Sauter J, Bult-Ito A \& McMahon DG 2003 Phase resetting light pulses induce Per1 and persistent spike activity in a subpopulation of biological clock neurons. Journal of Neuroscience $\mathbf{2 3}$ 1441-1450.

Lavialle M \& Serviere J 1993 Circadian fluctuations in GFAP distribution in the Syrian hamster suprachiasmatic nucleus. Neuroreport 4 1243-1246. (doi:10.1097/00001756-199309000-00008)

Lavaille M \& Serviere J 1995 Developmental study in the circadian clock of the golden hamster: a putative role of astrocytes. Developmental Brain Research 86 275-282. (doi:10.1016/0165-3806(95)00039-G)

Lavialle M, Begue A, Papillon C \& Vilaplana J 2001 Modifications of retinal afferent activity induce changes in astroglial plasticity in the hamster circadian clock. Glia 34 88-100. (doi:10.1002/glia.1044)

Leak RK \& Moore RY 2001 Topographic organization of suprachiasmatic nucleus projection neurons. Journal of Comparative Neurology 433 312-334. (doi:10.1002/cne.1142)

Lee W, Watanabe M \& Glass JD 1995 Photoperiod affects the expression of neural cell adhesion molecule and polysialic acid in the hypothalamus of the Siberian hamster. Brain Research 690 64-72. (doi:10.1016/0006-8993(95)00588-H)

Lee HS, Nelms JL, Nguyen M, Silver R \& Lehman MN 2003 The eye is necessary for a circadian rhythm in the suprachiasmatic nucleus. Nature Neuroscience 6 111-112. (doi:10.1038/nn1006)

Lee ML, Swanson BE \& de la Iglesia HO 2009 Circadian timing of REM sleep is coupled to an oscillator within the dorsomedial suprachiasmatic nucleus. Current Biology 19 848-852. (doi:10.1016/j. cub.2009.03.051)

Lee JE, Zamdborg L, Southey BR, Atkins N Jr, Mitchell JW, Li M, Gillette MU, Kelleher NL \& Sweedler JV 2013 Quantitative peptidomics for discovery of circadian-related peptides from the rat suprachiasmatic nucleus. Journal of Proteome Research 12 585-593. (doi:10.1021/pr300605p)

Lee IT, Chang AS, Manandhar M, Shan Y, Fan J, Izumo M, Ikeda Y, Motoike T, Dixon S, Seinfeld JE, et al. 2015 Neuromedin s-producing neurons act as essential pacemakers in the suprachiasmatic nucleus to couple clock neurons and dictate circadian rhythms. Neuron $\mathbf{8 5}$ 1086-1102. (doi:10.1016/j.neuron.2015.02.006)

Leise TL, Wang CW, Gitis PJ \& Welsh DK 2012 Persistent cell-autonomous circadian oscillations in fibroblasts revealed by six-week singlecell imaging of PER2::LUC bioluminescence. PLOS ONE 7 e33334. (doi:10.1371/journal.pone.0033334)

Lesauter J, Silver R, Cloues R \& Witkovsky P 2011 Light exposure induces short- and long-term changes in the excitability of retinorecipient neurons in suprachiasmatic nucleus. Journal of Neurophysiology $\mathbf{1 0 6}$ 576-588. (doi:10.1152/jn.00060.2011)

Li JD, Burton KJ, Zhang C, Hu SB \& Zhou QY 2009 Vasopressin receptor $\mathrm{V} 1 \mathrm{a}$ regulates circadian rhythms of locomotor activity and expression of clock-controlled genes in the suprachiasmatic nuclei. American Journal of Physiology: Regulatory, Integrative and Comparative Physiology 296 R824-R830. (doi:10.1152/ajpregu.90463.2008)

Lindley J, Deurveilher S, Rusak B \& Semba K 2008 Transforming growth factor-alpha and glial fibrillary acidic protein in the hamster circadian system: daily profile and cellular localization. Brain Research 1197 94-105. (doi:10.1016/j.brainres.2007.12.053)

Liou SY \& Albers HE 1989 Single unit response of suprachiasmatic neurons to arginine vasopressin (AVP) is mediated by a V1-like receptor in the hamster. Brain Research 477 336-343. (doi:10.1016/0006-8993(89)91424-8)

Liou SY, Shibata S, Albers HE \& Ueki S 1990 Effects of GABA and anxiolytics on the single unit discharge of suprachiasmatic neurons in rat hypothalamic slices. Brain Research Bulletin 25 103-107. (doi:10.1016/0361-9230(90)90259-3)

Liu C \& Reppert SM 2000 GABA synchronizes clock cells within the suprachiasmatic circadian clock. Neuron 25 123-128. (doi:10.1016/ S0896-6273(00)80876-4)

Liu C, Weaver DR, Strogatz SH \& Reppert SM 1997 Cellular construction of a circadian clock: period determination in the suprachiasmatic nuclei. Cell 91 855-860. (doi:10.1016/S0092-8674(00)80473-0) http://joe.endocrinology-journals.org

DOI: 10.1530/JOE-16-0054
() 2016 Society for Endocrinology Printed in Great Britain 
Liu AC, Welsh DK, Ko CH, Tran HG, Zhang EE, Priest AA, Buhr ED, Singer O, Meeker K, Verma IM, et al. 2007 Intercellular coupling confers robustness against mutations in the SCN circadian clock network. Cell 129 605-616. (doi:10.1016/j.cell.2007.02.047)

Locke JC, Westermark PO, Kramer A \& Herzel H 2008 Global parameter search reveals design principles of the mammalian circadian clock. BMC Systems Biology 2 22. (doi:10.1186/1752-0509-2-22)

Loh DH, Dragich JM, Kudo T, Schroeder AM, Nakamura TJ, Waschek JA, Block GD \& Colwell CS 2011 Effects of vasoactive intestinal peptide genotype on circadian gene expression in the suprachiasmatic nucleus and peripheral organs. Journal of Biological Rhythms $\mathbf{2 6}$ 200-209. (doi:10.1177/0748730411401740)

Loh DH, Kuljis DA, Azuma L, Wu Y, Truong D, Wang HB \& Colwell CS 2014 Disrupted reproduction, estrous cycle, and circadian rhythms in female mice deficient in vasoactive intestinal peptide. Journal of Biological Rhythms 29 355-369. (doi:10.1177/0748730414549767)

Lokshin M, LeSauter J \& Silver R 2015 Selective distribution of retinal input to mouse SCN revealed in analysis of sagittal sections. Journal of Biological Rhythms 30 251-257. (doi:10.1177/0748730415584058)

Long MA, Jutras MJ, Connors BW \& Burwell RD 2005 Electrical synapses coordinate activity in the suprachiasmatic nucleus. Nature Neuroscience 8 61-66. (doi:10.1038/nn1361)

Low-Zeddies SS \& Takahashi JS 2001 Chimera analysis of the Clock mutation in mice shows that complex cellular integration determines circadian behavior. Cell 105 25-42. (doi:10.1016/S0092-8674(01)00294-X)

Lucassen EA, van Diepen HC, Houben T, Michel S, Colwell CS \& Meijer JH 2012 Role of vasoactive intestinal peptide in seasonal encoding by the suprachiasmatic nucleus clock. European Journal of Neuroscience 35 1466-1474. (doi:10.1111/j.1460-9568.2012.08054.x)

Ludwig M \& Leng G 2006 Dendritic peptide release and peptidedependent behaviours. Nature Reviews Neuroscience 7 126-136. (doi:10.1038/nrn1845)

Mackey SR 2007 Biological rhythms workshop IA: molecular basis of rhythms generation. Cold Spring Harbor Symposia on Quantitative Biology 72 7-19. (doi:10.1101/sqb.2007.72.060)

Mahoney MM, Ramanathan C, Hagenauer MH, Thompson RC, Smale L \& Lee T 2009 Daily rhythms and sex differences in vasoactive intestinal polypeptide, VIPR2 receptor and arginine vasopressin mRNA in the suprachiasmatic nucleus of a diurnal rodent, Arvicanthis niloticus. European Journal of Neuroscience 30 1537-1543. (doi:10.1111/ j.1460-9568.2009.06936.x)

Marpegan L, Krall TJ \& Herzog ED 2009 Vasoactive intestinal polypeptide entrains circadian rhythms in astrocytes. Journal of Biological Rhythms 24 135-143. (doi:10.1177/0748730409332042)

Marty A \& Llano I 2005 Excitatory effects of GABA in established brain networks. Trends in Neurosciences 28 284-289. (doi:10.1016/j. tins.2005.04.003)

Mason R, Biello SM \& Harrington ME 1991 The effects of GABA and benzodiazepines on neurones in the suprachiasmatic nucleus (SCN) of Syrian hamsters. Brain Research 552 53-57. (doi:10.1016/00068993(91)90659-J)

Maybauer MO, Maybauer DM, Enkhbaatar P \& Traber DL 2008 Physiology of the vasopressin receptors. Best Practice \& Research Clinical Anaesthesiology 22 253-263.

Maywood ES, Reddy AB, Wong GK, O’Neill JS, O’Brien JA, McMahon DG Harmar AJ, Okamura H \& Hastings MH 2006 Synchronization and maintenance of timekeeping in suprachiasmatic circadian clock cells by neuropeptidergic signaling. Current Biology 16 599-605. (doi:10.1016/j.cub.2006.02.023)

Maywood ES, Chesham JE, O’Brien JA \& Hastings MH 2011 A diversity of paracrine signals sustains molecular circadian cycling in suprachiasmatic nucleus circuits. PNAS 108 14306-14311. (doi:10.1073/pnas.1101767108)

Maywood ES, Drynan L, Chesham JE, Edwards MD, Dardente H, Fustin JM, Hazlerigg DG, O’Neill JS, Codner GF, Smyllie NJ, et al. 2013 Analysis of core circadian feedback loop in suprachiasmatic nucleus of mCry1-luc transgenic reporter mouse. PNAS $1109547-9552$. (doi:10.1073/pnas.1220894110)

McArthur AJ, Coogan AN, Ajpru S, Sugden D, Biello SM \& Piggins HD 2000 Gastrin-releasing peptide phase-shifts suprachiasmatic nuclei neuronal rhythms in vitro. Journal of Neuroscience 20 5496-5502.

Meijer JH, Groos GA \& Rusak B 1986 Luminance coding in a circadian pacemaker: the suprachiasmatic nucleus of the rat and the hamster. Brain Research 382 109-118. (doi:10.1016/0006-8993(86)90117-4)

Meijer JH, Colwell CS, Rohling JH, Houben T \& Michel S 2012 Dynamic neuronal network organization of the circadian clock and possible deterioration in disease. Progress in Brain Research 199 143-162. (doi:10.1016/B978-0-444-59427-3.00009-5)

Menaker M 1961 The free running period of the bat clock; seasonal variations at low body temperature. Journal of Cellular and Comparative Physiology 57 81-86. (doi:10.1002/jcp.1030570204)

Meyer-Spasche A \& Piggins HD 2004 Vasoactive intestinal polypeptide phase-advances the rat suprachiasmatic nuclei circadian pacemaker in vitro via protein kinase A and mitogen-activated protein kinase. Neuroscience Letters 358 91-94. (doi:10.1016/j.neulet.2003.12.114)

Michel S \& Colwell CS 2001 Cellular communication and coupling within the suprachiasmatic nucleus. Chronobiology International 18 579-600. (doi:10.1081/CBI-100106074)

Michel S, Marek R, Vanderleest HT, Vansteensel MJ, Schwartz WJ, Colwell CS \& Meijer JH 2013 Mechanism of bilateral communication in the suprachiasmatic nucleus. European Journal of Neuroscience $\mathbf{3 7}$ 964-971. (doi:10.1111/ejn.12109)

Mieda M, Ono D, Hasegawa E, Okamoto H, Honma K, Honma S \& Sakurai T 2015 Cellular clocks in AVP neurons of the SCN are critical for interneuronal coupling regulating circadian behavior rhythm. Neuron 85 1103-1116. (doi:10.1016/j.neuron.2015.02.005)

Mihai R, Juss TS \& Ingram CD 1994 Suppression of suprachiasmatic nucleus neurone activity with a vasopressin receptor antagonist: possible role for endogenous vasopressin in circadian activity cycles in vitro. Neuroscience Letters 179 95-99. (doi:10.1016/03043940(94)90943-1)

Miller BH, Olson SL, Levine JE, Turek FW, Horton TH \& Takahashi JS 2006 Vasopressin regulation of the proestrous luteinizing hormone surge in wild-type and Clock mutant mice. Biology of Reproduction $\mathbf{7 5}$ 778-784. (doi:10.1095/biolreprod.106.052845)

Mintz EM, Jasnow AM, Gillespie CF, Huhman KL \& Albers HE 2002 GABA interacts with photic signaling in the suprachiasmatic nucleus to regulate circadian phase shifts. Neuroscience 109 773-778. (doi:10.1016/S0306-4522(01)00519-X)

Moga MM \& Moore RY 1997 Organization of neural inputs to the suprachiasmatic nucleus in the rat. Journal of Comparative Neurology 389 508-534. (doi:10.1002/(SICI)10969861(19971222)389:3<508::AID-CNE11>3.0.CO;2-H)

Mohawk JA \& Takahashi JS 2011 Cell autonomy and synchrony of suprachiasmatic nucleus circadian oscillators. Trends in Neurosciences 34 349-358. (doi:10.1016/j.tins.2011.05.003)

Mohawk JA, Green CB \& Takahashi JS 2012 Central and peripheral circadian clocks in mammals. Annual Review of Neuroscience $\mathbf{3 5}$ 445-462. (doi:10.1146/annurev-neuro-060909-153128)

Moore RY 1991 Disorders of circadian function and the human circadian timing system. In Suprachiasmatic Nucleus: The Mind's Clock. Eds DC Klein, RY Moore \& SM Reppert. New York, NY, USA: University Oxford Press.

Moore RY \& Silver R 1998 Suprachiasmatic nucleus organization. Chronobiology International 15 475-487. (doi:10.3109/07420529808998703)

Moore RY \& Speh JC 1993 GABA is the principal neurotransmitter of the circadian system. Neuroscience Letters 150 112-116. (doi:10.1016/0304-3940(93)90120-A)

Moore RY, Speh JC \& Leak RK 2002 Suprachiasmatic nucleus organization. Cell and Tissue Research 309 89-98. (doi:10.1007/ s00441-002-0575-2) 
Morin LP 2007 SCN organization reconsidered. Journal of Biological Rhythms 22 3-13. (doi:10.1177/0748730406296749)

Morin LP 2012 Neuroanatomy of the extended circadian rhythm system. Experimental Neurology 243 4-20. (doi:10.1016/j. expneurol.2012.06.026)

Morin LP \& Allen CN 2006 The circadian visual system, 2005. Brain Research. Brain Research Reviews 51 1-60. (doi:10.1016/j. brainresrev.2005.08.003)

Moriya T, Yoshinobu Y, Kouzu Y, Katoh A, Gomi H, Ikeda M, Yoshioka T, Itohara S \& Shibata S 2000 Involvement of glial fibrillary acidic protein (GFAP) expressed in astroglial cells in circadian rhythm under constant lighting conditions in mice. Journal of Neuroscience Research 60 212-218. (doi:10.1002/(sici)1097-4547(20000415)60:2<212::aidjnr10>3.0.co;2-p)

Myung J, Hong S, Hatanaka F, Nakajima Y, De Schutter E \& Takumi T 2012 Period coding of Bmal1 oscillators in the suprachiasmatic nucleus. Journal of Neuroscience 32 8900-8918. (doi:10.1523/ JNEUROSCI.5586-11.2012)

Myung J, Hong S, DeWoskin D, De Schutter E, Forger DB \& Takumi T 2015 GABA-mediated repulsive coupling between circadian clock neurons in the SCN encodes seasonal time. PNAS 112 E3920-E3929. (doi:10.1073/pnas.1421200112)

Nagano M, Adachi A, Nakahama K, Nakamura T, Tamada M, MeyerBernstein E, Sehgal A \& Shigeyoshi Y 2003 An abrupt shift in the day/ night cycle causes desynchrony in the mammalian circadian center. Journal of Neuroscience 23 6141-6151.

Nagoshi E, Saini C, Bauer C, Laroche T, Naef F \& Schibler U 2004 Circadian gene expression in individual fibroblasts: cell-autonomous and self-sustained oscillators pass time to daughter cells. Cell 119 693-705. (doi:10.1016/j.cell.2004.11.015)

Naito E, Watanabe T, Tei H, Yoshimura T \& Ebihara S 2008 Reorganization of the suprachiasmatic nucleus coding for day length. Journal of Biological Rhythms 23 140-149. (doi:10.1177/0748730408314572)

Nakamura W, Honma S, Shirakawa T \& Honma K 2001 Regional pacemakers composed of multiple oscillator neurons in the rat suprachiasmatic nucleus. European Journal of Neuroscience 14 666-674. (doi:10.1046/j.0953-816x.2001.01684.x)

Nakamura W, Honma S, Shirakawa T \& Honma K 2002 Clock mutation lengthens the circadian period without damping rhythms in individual SCN neurons. Nature Neuroscience 5 399-400. (doi:10.1080/ 1028415021000055943)

Nakamura TJ, Fujimura K, Ebihara S \& Shinohara K 2004 Light response of the neuronal firing activity in the suprachiasmatic nucleus of mice. Neuroscience Letters 371 244-248. (doi:10.1016/j.neulet.2004.09.005)

Nakamura W, Yamazaki S, Takasu NN, Mishima K \& Block GD 2005 Differential response of Period1 expression within the suprachiasmatic nucleus. Journal of Neuroscience 25 5481-5487. (doi:10.1523/ JNEUROSCI.0889-05.2005)

Natalucci G, Riedl S, Gleiss A, Zidek T \& Frisch H 2005 Spontaneous 24-h ghrelin secretion pattern in fasting subjects: maintenance of a meal-related pattern. European Journal of Endocrinology 152 845-850. (doi:10.1530/eje.1.01919)

Naum OG, Fernanda Rubio M \& Golombek DA 2001 Rhythmic variation in gamma-aminobutyric acid(A)-receptor subunit composition in the circadian system and median eminence of Syrian hamsters. Neuroscience Letters 310 178-182. (doi:10.1016/S03043940(01)02129-2)

Nielsen HS, Hannibal J \& Fahrenkrug J 2002 Vasoactive intestinal polypeptide induces per 1 and per2 gene expression in the rat suprachiasmatic nucleus late at night. European Journal of Neuroscience 15 570-574. (doi:10.1046/j.0953-816x.2001.01882.x)

Noguchi T \& Watanabe K 2008 Regional differences in circadian period within the suprachiasmatic nucleus. Brain Research 1239 119-126. (doi:10.1016/j.brainres.2008.08.082)
Noguchi T, Michihata T, Nakamura W, Takumi T, Shimizu R, Yamamoto M, Ikeda M, Ohmiya Y \& Nakajima Y 2010 Dual-color luciferase mouse directly demonstrates coupled expression of two clock genes. Biochemistry 49 8053-8061. (doi:10.1021/bi100545h)

Novak CM, Ehlen JC, Huhman KL \& Albers HE 2004 GABA(B) receptor activation in the suprachiasmatic nucleus of diurnal and nocturnal rodents. Brain Research Bulletin 63 531-535. (doi:10.1016/j. brainresbull.2004.05.001)

O'Hara BF, Andretic R, Heller HC, Carter DB \& Kilduff TS 1995 GABAA, GABAC, and NMDA receptor subunit expression in the suprachiasmatic nucleus and other brain regions. Brain Research. Molecular Brain Research 28 239-250.

Okamura H, Berod A, Julien JF, Geffard M, Kitahama K, Mallet J \& Bobillier P 1989 Demonstration of GABAergic cell bodies in the suprachiasmatic nucleus: in situ hybridization of glutamic acid decarboxylase (GAD) mRNA and immunocytochemistry of GAD and GABA. Neuroscience Letters 102 131-136. (doi:10.1016/03043940(89)90067-0)

Pakhotin P, Harmar AJ, Verkhratsky A \& Piggins H 2006 VIP receptors control excitability of suprachiasmatic nuclei neurones. Pflügers Archiv 452 7-15. (doi:10.1007/s00424-005-0003-z)

Piggins HD, Antle MC \& Rusak B 1995 Neuropeptides phase shift the mammalian circadian pacemaker. Journal of Neuroscience $\mathbf{1 5}$ 5612-5622.

Piggins HD, Goguen D \& Rusak B 2005 Gastrin-releasing peptide induces c-Fos in the hamster suprachiasmatic nucleus. Neuroscience Letters $\mathbf{3 8 4}$ 205-210. (doi:10.1016/j.neulet.2005.03.072)

Prolo LM, Takahashi JS \& Herzog ED 2005 Circadian rhythm generation and entrainment in astrocytes. Journal of Neuroscience 25 404-408. (doi:10.1523/JNEUROSCI.4133-04.2005)

Prosser RA, Edgar DM, Heller HC \& Miller JD 1994 A possible glial role in the mammalian circadian clock. Brain Research 643 296-301. (doi:10.1016/0006-8993(94)90036-1)

Quintero JE, Kuhlman SJ \& McMahon DG 2003 The biological clock nucleus: a multiphasic oscillator network regulated by light. Journal of Neuroscience 23 8070-8076.

Rash JE, Staines WA, Yasumura T, Patel D, Furman CS, Stelmack GL \& Nagy JI 2000 Immunogold evidence that neuronal gap junctions in adult rat brain and spinal cord contain connexin-36 but not connexin-32 or connexin-43. PNAS 97 7573-7578. (doi:10.1073/ pnas.97.13.7573)

Rash JE, Yasumura T, Dudek FE \& Nagy JI 2001 Cell-specific expression of connexins and evidence of restricted gap junctional coupling between glial cells and between neurons. Journal of Neuroscience $\mathbf{2 1}$ 1983-2000.

Reppert S 1992 Pre-natal development of a hypothalamic biological clock. Progress in Brain Research 93 119-132.

Rohling J, Meijer JH, VanderLeest HT \& Admiraal J 2006 Phase differences between SCN neurons and their role in photoperiodic encoding; a simulation of ensemble patterns using recorded single unit electrical activity patterns. Journal of Physiology $\mathbf{1 0 0} 261-270$.

Rohling JH, Vanderleest HT, Michel S, Vansteensel MJ \& Meijer JH 2011 Phase resetting of the mammalian circadian clock relies on a rapid shift of a small population of pacemaker neurons. PLOS ONE 6 e25437. (doi:10.1371/journal.pone.0025437)

Romijn HJ, Sluiter AA, Pool CW, Wortel J \& Buijs RM 1997 Evidence from confocal fluorescence microscopy for a dense, reciprocal innervation between AVP-, somatostatin-, VIP/PHI-, GRP-, and VIP/PHI/GRPimmunoreactive neurons in the rat suprachiasmatic nucleus. European Journal of Neuroscience 9 2613-2623. (doi:10.1111/j.1460-9568.1997. tb01691.x)

Russell W, Harrison RF, Smith N, Darzy K, Shalet S, Weetman AP \& Ross RJ 2008 Free triiodothyronine has a distinct circadian rhythm that is delayed but parallels thyrotropin levels. Journal of Clinical Endocrinology \& Metabolism 93 2300-2306. http://joe.endocrinology-journals.org

DOI: 10.1530/JOE-16-0054
(C) 2016 Society for Endocrinology Printed in Great Britain 
Saeb-Parsy K \& Dyball RE 2003 Defined cell groups in the rat suprachiasmatic nucleus have different day/night rhythms of single-unit activity in vivo. Journal of Biological Rhythms 18 26-42. (doi:10.1177/0748730402239674)

Schaap J, Albus H, VanderLeest HT, Eilers PH, Detari L \& Meijer JH 2003 Heterogeneity of rhythmic suprachiasmatic nucleus neurons: implications for circadian waveform and photoperiodic encoding. PNAS 100 15994-15999. (doi:10.1073/pnas.2436298100)

Schroder H, Stehle J \& Henschel M 1988 Twenty-four-hour pineal melatonin synthesis in the vasopressin-deficient Brattleboro rat. Brain Research 459 328-332. (doi:10.1016/0006-8993(88)90648-8)

Schroeder A, Loh DH, Jordan MC, Roos KP \& Colwell CS 2011 Circadian regulation of cardiovascular function: a role for vasoactive intestinal peptide. American Journal of Physiology: Heart and Circulatory Physiology 300 H241-H250. (doi:10.1152/ajpheart.00190.2010)

Schwartz WJ 1991 Further evaluation of the tetrodotoxin-resistant circadian pacemaker in the suprachiasmatic nuclei. Journal of Biological Rhythms 6 149-158. (doi:10.1177/074873049100600205)

Schwartz WJ \& Gainer H 1977 Suprachiasmatic nucleus: use of 14C-labeled deoxyglucose uptake as a functional marker. Science $\mathbf{1 9 7}$ 1089-1091. (doi:10.1126/science.887940)

Schwartz WJ, Gross RA \& Morton MT 1987 The suprachiasmatic nuclei contain a tetrodotoxin-resistant circadian pacemaker. PNAS $\mathbf{8 4}$ 1694-1698. (doi:10.1073/pnas.84.6.1694)

Schwartz WJ, Carpino A Jr, de la Iglesia HO, Baler R, Klein DC, Nakabeppu Y \& Aronin N 2000 Differential regulation of fos family genes in the ventrolateral and dorsomedial subdivisions of the rat suprachiasmatic nucleus. Neuroscience 98 535-547. (doi:10.1016/ S0306-4522(00)00140-8)

Schwartz MD, Wotus C, Liu T, Friesen WO, Borjigin J, Oda GA \& de la Iglesia HO 2009 Dissociation of circadian and light inhibition of melatonin release through forced desynchronization in the rat. PNAS 106 17540-17545. (doi:10.1073/pnas.0906382106)

Sellix MT, Evans JA, Leise TL, Castanon-Cervantes O, Hill DD, DeLisser P, Block GD, Menaker M \& Davidson AJ 2012 Aging differentially affects the re-entrainment response of central and peripheral circadian oscillators. Journal of Neuroscience 32 16193-16202. (doi:10.1523/ JNEUROSCI.3559-12.2012)

Shen S, Spratt C, Sheward WJ, Kallo I, West K, Morrison CF, Coen CW, Marston HM \& Harmar AJ 2000 Overexpression of the human VPAC2 receptor in the suprachiasmatic nucleus alters the circadian phenotype of mice. PNAS 97 11575-11580. (doi:10.1073/ pnas.97.21.11575)

Sheward WJ, Naylor E, Knowles-Barley S, Armstrong JD, Brooker GA, Seckl JR, Turek FW, Holmes MC, Zee PC \& Harmar AJ 2010 Circadian control of mouse heart rate and blood pressure by the suprachiasmatic nuclei: behavioral effects are more significant than direct outputs. PLOS ONE 5 e9783. (doi:10.1371/journal. pone.0009783)

Shibata S \& Moore RY 1987 Development of neuronal activity in the rat suprachiasmatic nucleus. Brain Research 431 311-315. (doi:10.1016/0165-3806(87)90220-3)

Shibata S \& Moore RY 1993 Tetrodotoxin does not affect circadian rhythms in neuronal activity and metabolism in rodent suprachiasmatic nucleus in vitro. Brain Research 606 259-266. (doi:10.1016/0006-8993(93)90993-W)

Shibata S, Liou S, Ueki S \& Oomura Y 1984 Influence of environmental light-dark cycle and enucleation on activity of suprachiasmatic neurons in slice preparations. Brain Research 302 75-81. (doi:10.1016/0006-8993(84)91286-1)

Shimizu K, Nagai K \& Nakagawa H 1996 An immunotoxin, antiVIP antibody-ricin A chain conjugate eliminates neurons in the hypothalamic suprachiasmatic nucleus selectively and abolishes the circadian rhythm of water intake. Brain Research Bulletin 41 369-378. (doi:10.1016/S0361-9230(96)00070-6)
Shimura M, Harata N, Tamai M \& Akaike N 1996 Allosteric modulation of GABAA receptors in acutely dissociated neurons of the suprachiasmatic nucleus. American Journal of Physiology $\mathbf{2 7 0}$ C1726-C1734.

Shinohara K \& Inouye ST 1995 Photic information coded by vasoactive intestinal polypeptide and neuropeptide Y. Neuroscience \& Biobehavioral Reviews 19 349-352.

Shinohara K, Tominaga K, Isobe Y \& Inouye ST 1993 Photic regulation of peptides located in the ventrolateral subdivision of the suprachiasmatic nucleus of the rat: daily variations of vasoactive intestinal polypeptide, gastrin-releasing peptide, and neuropeptide Y. Journal of Neuroscience 13 793-800.

Shinohara K, Honma S, Katsuno Y, Abe H \& Honma K 1995 Two distinct oscillators in the rat suprachiasmatic nucleus in vitro. PNAS 92 7396-7400. (doi:10.1073/pnas.92.16.7396)

Shinohara K, Honma S, Katsuno Y, Abe H \& Honma K 1998 Circadian release of amino acids in the suprachiasmatic nucleus in vitro. Neuroreport 9 137-140. (doi:10.1097/00001756-199801050-00027)

Shinohara K, Funabashi T, Mitushima D \& Kimura F $2000 a$ Effects of gap junction blocker on vasopressin and vasoactive intestinal polypeptide rhythms in the rat suprachiasmatic nucleus in vitro. Neuroscience Research 38 43-47.

Shinohara K, Hiruma H, Funabashi T \& Kimura F 2000b GABAergic modulation of gap junction communication in slice cultures of the rat suprachiasmatic nucleus. Neuroscience 96 591-596.

Shirakawa T, Honma S, Katsuno Y, Oguchi H \& Honma KI 2000 Synchronization of circadian firing rhythms in cultured rat suprachiasmatic neurons. European Journal of Neuroscience 12 2833-2838. (doi:10.1046/j.1460-9568.2000.00170.x)

Shirakawa T, Honma S \& Honma K 2001 Multiple oscillators in the suprachiasmatic nucleus. Chronobiology International 18 371-387. (doi:10.1081/CBI-100103962)

Silver R, Romero MT, Besmer HR, Leak R, Nunez JM \& LeSauter J 1996 Calbindin-D28K cells in the hamster SCN express light-induced Fos. Neuroreport 7 1224-1228. (doi:10.1097/00001756-199604260-00026)

Smarr BL, Morris E \& de la Iglesia HO 2012 The dorsomedial suprachiasmatic nucleus times circadian expression of Kiss 1 and the luteinizing hormone surge. Endocrinology 153 2839-2850. (doi:10.1210/en.2011-1857)

Smith L \& Canal MM 2009 Expression of circadian neuropeptides in the hypothalamus of adult mice is affected by postnatal light experience. Journal of Neuroendocrinology 21 946-953. (doi:10.1111/j.13652826.2009.01914.x)

Strecker GJ, Wuarin JP \& Dudek FE 1997 GABAA-mediated local synaptic pathways connect neurons in the rat suprachiasmatic nucleus. Journal of Neurophysiology 78 2217-2220.

Sukhov RR, Walker LC, Rance NE, Price DL \& Young WS 3rd 1993 Vasopressin and oxytocin gene expression in the human hypothalamus. Journal of Comparative Neurology 337 295-306. (doi:10.1002/cne.903370210)

Takahashi Y, Kipnis DM \& Daughaday WH 1968 Growth hormone secretion during sleep. Journal of Clinical Investigation 47 2079-2090. (doi:10.1172/JCI105893)

Takahashi Y, Okamura H, Yanaihara N, Hamada S, Fujita S \& Ibata Y 1989 Vasoactive intestinal peptide immunoreactive neurons in the rat suprachiasmatic nucleus demonstrate diurnal variation. Brain Research 497 374-377. (doi:10.1016/0006-8993(89)90283-7)

Tamada Y, Tanaka M, Munekawa K, Hayashi S, Okamura H, Kubo T, Hisa Y \& Ibata Y 1998 Neuron-glia interaction in the suprachiasmatic nucleus: a double labeling light and electron microscopic immunocytochemical study in the rat. Brain Research Bulletin $\mathbf{4 5}$ 281-287. (doi:10.1016/S0361-9230(97)00403-6)

Tousson E \& Meissl H 2004 Suprachiasmatic nuclei grafts restore the circadian rhythm in the paraventricular nucleus of the hypothalamus. Journal of Neuroscience 24 2983-2988. (doi:10.1523/JNEUROSCI.5044-03.2004) http://joe.endocrinology-journals.org

DOI: 10.1530/JOE-16-0054
(C) 2016 Society for Endocrinology Printed in Great Britain
Published by Bioscientifica Ltd. 
Van den Pol AN 1980 The hypothalamic suprachiasmatic nucleus of rat: intrinsic anatomy. Journal of Comparative Neurology 191 661-702. (doi:10.1002/cne.901910410)

van den Pol AN 2012 Neuropeptide transmission in brain circuits. Neuron 76 98-115. (doi:10.1016/j.neuron.2012.09.014)

van den Pol AN \& Dudek FE 1993 Cellular communication in the circadian clock, the suprachiasmatic nucleus. Neuroscience 56 793-811. (doi:10.1016/0306-4522(93)90128-3)

van den Pol AN \& Tsujimoto KL 1985 Neurotransmitters of the hypothalamic suprachiasmatic nucleus: immunocytochemical analysis of 25 neuronal antigens. Neuroscience 15 1049-1086. (doi:10.1016/0306-4522(85)90254-4)

van den Pol AN, Finkbeiner SM \& Cornell-Bell AH 1992 Calcium excitability and oscillations in suprachiasmatic nucleus neurons and glia in vitro. Journal of Neuroscience 12 2648-2664.

van der Beek EM, Wiegant VM, van der Donk HA, van den Hurk R \& Buijs RM 1993 Lesions of the suprachiasmatic nucleus indicate the presence of a direct vasoactive intestinal polypeptidecontaining projection to gonadotrophin-releasing hormone neurons in the female rat. Journal of Neuroendocrinology 5 137-144. (doi:10.1111/j.1365-2826.1993.tb00373.x)

Van der Veen DR, Castillo MR, Van der Zee EA, Jansen K, Gerkema MP \& Bult-Ito A 2005 Circadian dynamics of vasopressin in mouse selection lines: translation and release in the SCN. Brain Research 1060 16-25. (doi:10.1016/j.brainres.2005.07.068)

van Esseveldt KE, Lehman MN \& Boer GJ 2000 The suprachiasmatic nucleus and the circadian time-keeping system revisited. Brain Research. Brain Research Reviews 33 34-77. (doi:10.1016/S01650173(00)00025-4)

Vogt K 2015 Diversity in GABAergic signaling. Advances in Pharmacology 73 203-222. (doi:10.1016/bs.apha.2014.11.009)

Vosko AM, Schroeder A, Loh DH \& Colwell CS 2007 Vasoactive intestinal peptide and the mammalian circadian system. General and Comparative Endocrinology 152 165-175. (doi:10.1016/j. ygcen.2007.04.018)

Wagner S, Castel M, Gainer H \& Yarom Y 1997 GABA in the mammalian suprachiasmatic nucleus and its role in diurnal rhythmicity. Nature 387 598-603. (doi:10.1038/42468)

Wang D, Cui LN \& Renaud LP 2003 Pre- and postsynaptic GABA(B) receptors modulate rapid neurotransmission from suprachiasmatic nucleus to parvocellular hypothalamic paraventricular nucleus neurons. Neuroscience 118 49-58. (doi:10.1016/S0306-4522(02)00906-5)

Wang MH, Chen N \& Wang JH 2014 The coupling features of electrical synapses modulate neuronal synchrony in hypothalamic superachiasmatic nucleus. Brain Research 1550 9-17. (doi:10.1016/j. brainres.2014.01.007)

Watanabe K, Vanecek J \& Yamaoka S 2000 In vitro entrainment of the circadian rhythm of vasopressin-releasing cells in suprachiasmatic nucleus by vasoactive intestinal polypeptide. Brain Research $\mathbf{8 7 7}$ 361-366. (doi:10.1016/S0006-8993(00)02724-4)

Watts AG 1991 The efferent projections of the suprachiasmatic nucleus: anatomical insights into the control of circadian rhythms. In Suprachiasmatic Nucleus: The Mind's Clock, pp 77-106. Eds DC Klein, RY Moore \& SM Reppert. New York, NY, USA: University of Oxford Press.

Watts AG \& Swanson LW 1987 Efferent projections of the suprachiasmatic nucleus: II. Studies using retrograde transport of fluorescent dyes and simultaneous peptide immunohistochemistry in the rat. Journal of Comparative Neurology 258 230-252. (doi:10.1002/ cne.902580205)

Weaver DR 1998 The suprachiasmatic nucleus: a 25-year retrospective. Journal of Biological Rhythms 13 100-112. (doi:10.1177/07487309812 8999952)

Webb AB, Angelo N, Huettner JE \& Herzog ED 2009 Intrinsic, nondeterministic circadian rhythm generation in identified mammalian neurons. PNAS 106 16493-16498. (doi:10.1073/ pnas.0902768106)

Welsh DK, Logothetis DE, Meister M \& Reppert SM 1995 Individual neurons dissociated from rat suprachiasmatic nucleus express independently phased circadian firing rhythms. Neuron 14 697-706. (doi:10.1016/0896-6273(95)90214-7)

Welsh DK, Yoo SH, Liu AC, Takahashi JS \& Kay SA 2004 Bioluminescence imaging of individual fibroblasts reveals persistent, independently phased circadian rhythms of clock gene expression. Current Biology 14 2289-2295. (doi:10.1016/j.cub.2004.11.057)

Welsh DK, Takahashi JS \& Kay SA 2010 Suprachiasmatic nucleus: cell autonomy and network properties. Annual Review of Physiology $\mathbf{7 2}$ 551-577. (doi:10.1146/annurev-physiol-021909-135919)

Wideman CH, Murphy HM \& Nadzam GR 2000 Vasopressin deficiency provides evidence for separate circadian oscillators of activity and temperature. Peptides 21 811-816. (doi:10.1016/S01969781(00)00213-8)

Womac AD, Burkeen JF, Neuendorff N, Earnest DJ \& Zoran MJ 2009 Circadian rhythms of extracellular ATP accumulation in suprachiasmatic nucleus cells and cultured astrocytes. European Journal of Neuroscience 30 869-876. (doi:10.1111/j.14609568.2009.06874.x)

Wotus C, Lilley TR, Neal AS, Suleiman NL, Schmuck SC, Smarr BL, Fischer BJ \& de la Iglesia HO 2013 Forced desynchrony reveals independent contributions of suprachiasmatic oscillators to the daily plasma corticosterone rhythm in male rats. PLOS ONE 8 e68793.

Yagita K, Yamanaka I, Emoto N, Kawakami K \& Shimada S 2010 Realtime monitoring of circadian clock oscillations in primary cultures of mammalian cells using Tol2 transposon-mediated gene transfer strategy. BMC Biotechnology 10 3. (doi:10.1186/1472-6750-10-3)

Yamaguchi S, Isejima H, Matsuo T, Okura R, Yagita K, Kobayashi M \& Okamura H 2003 Synchronization of cellular clocks in the suprachiasmatic nucleus. Science 302 1408-1412. (doi:10.1126/ science.1089287)

Yamaguchi Y, Suzuki T, Mizoro Y, Kori H, Okada K, Chen Y, Fustin JM, Yamazaki F, Mizuguchi N, Zhang J, et al. 2013 Mice genetically deficient in vasopressin $\mathrm{V} 1 \mathrm{a}$ and $\mathrm{V} 1 \mathrm{~b}$ receptors are resistant to jet lag. Science 342 85-90. (doi:10.1126/science.1238599)

Yamazaki S, Numano R, Abe M, Hida A, Takahashi R, Ueda M, Block GD, Sakaki Y, Menaker M \& Tei H 2000 Resetting central and peripheral circadian oscillators in transgenic rats. Science 288 682-685. (doi:10.1126/science.288.5466.682)

Yan L \& Okamura H 2002 Gradients in the circadian expression of Per1 and Per2 genes in the rat suprachiasmatic nucleus. European Journal of Neuroscience 15 1153-1162. (doi:10.1046/j.1460-9568.2002.01955.x)

Yan L \& Silver R 2002 Differential induction and localization of mPer1 and mPer2 during advancing and delaying phase shifts. European Journal of Neuroscience 16 1531-1540. (doi:10.1046/j.14609568.2002.02224.x)

Yan L \& Silver R 2004 Resetting the brain clock: time course and localization of MPER1 and MPER2 protein expression in suprachiasmatic nuclei during phase shifts. European Journal of Neuroscience 19 1105-1109.

Yan L, Foley NC, Bobula JM, Kriegsfeld LJ \& Silver R 2005 Two antiphase oscillations occur in each suprachiasmatic nucleus of behaviorally split hamsters. Journal of Neuroscience 25 9017-9026.

Yan L, Karatsoreos I, Lesauter J, Welsh DK, Kay S, Foley D \& Silver R 2007 Exploring spatiotemporal organization of SCN circuits. Cold Spring Harbor Symposia on Quantitative Biology 72 527-541. (doi:10.1101/ sqb.2007.72.037)

Yoo SH, Yamazaki S, Lowrey PL, Shimomura K, Ko $\mathrm{CH}$ Buhr ED, Siepka SM, Hong HK, Oh WJ, Yoo OJ, et al. 2004 PERIOD2::LUCIFERASE real-time reporting of circadian dynamics reveals persistent circadian oscillations in mouse peripheral tissues. PNAS 101 5339-5346. http://joe.endocrinology-journals.org

DOI: $10.1530 / J O E-16-0054$
(C) 2016 Society for Endocrinology Printed in Great Britain 
Yoshikawa T, Nakajima Y, Yamada Y, Enoki R, Watanabe K, Yamazaki M, Sakimura K, Honma S \& Honma K 2015 Spatiotemporal profiles of arginine vasopressin transcription in cultured suprachiasmatic nucleus. European Journal of Neuroscience 42 2678-2689. (doi:10.1111/ ejn.13061)

Zhang EE \& Kay SA 2010 Clocks not winding unravelling circadian networks. Nature Reviews Molecular Cell Biology 11 764-776. (doi:10.1038/nrm2995)
Zhang R, Lahens NF, Ballance HI, Hughes ME \& Hogenesch JB 2014 A circadian gene expression atlas in implications for biology and medicine. PNAS 111 16219-16224. (doi:10.1073/pnas.1408886111) Zhou QY \& Cheng MY 2005 Prokineticin 2 and circadian clock output. FEBS Journal 272 5703-5709.

Zhou JN, Hofman MA \& Swaab DF 1995 VIP neurons in the human SCN in relation to sex, age, and Alzheimer's disease. Neurobiology of Aging 16 571-576.

Received in final form 11 April 2016

Accepted 6 May 2016

Accepted Preprint published online 6 May 2016
Published by Bioscientifica Ltd. 